Article

\title{
Deficit Irrigation and Its Implications for HydroSOStainable Almond Production
}

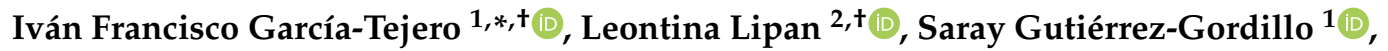 \\ Víctor Hugo Durán Zuazo ${ }^{3}{ }^{\circ}$, I. Jančo ${ }^{4}$, F. Hernández ${ }^{5}{ }^{\circledR}$, Belén Cárceles Rodríguez ${ }^{3}$ and \\ Ángel Antonio Carbonell-Barrachina ${ }^{2}$ (1) \\ 1 Centro IFAPA “Las Torres”. Ctra. Sevilla-Cazalla, km 12.2, Alcalá del Río, 41200 Sevilla, Spain; \\ saray.gutierrez@juntadeandalucia.es \\ 2 Department of Agro-Food Technology, University Miguel Hernández-EPSO, Carretera de Beniel, km 3.2, \\ Orihuela, 03312 Alicante, Spain; leontina.lipan@goumh.umh.es (L.L.); angel.carbonell@umh.es (Á.A.C.-B.) \\ 3 Centro IFAPA “Camino de Purchil”, Camino de Purchil s/n, 18004 Granada, Spain; \\ victorh.duran@juntadeandalucia.es (V.H.D.Z.); belen.carceles@juntadeandalucia.es (B.C.R.) \\ 4 Department of Chemistry, Faculty of Biotechnology and Food Sciences, Slovak University of Agriculture \\ in Nitra, Tr.A. Hlinku 2, 94976 Nitra, Slovakia; ivonajanco@gmail.com \\ 5 Department of Plant Science and Microbiology, University Miguel Hernández-EPSO, Carretera de Beniel, \\ km 3.2, Orihuela, 03312 Alicante, Spain; francisca.hernandez@umh.es \\ * Correspondence: ivanf.garcia@juntadeandalucia.es \\ + These authors had an equally contribution.
}

Received: 1 October 2020; Accepted: 21 October 2020; Published: 23 October 2020

\begin{abstract}
Deficit irrigation (DI) strategies are considered essential in many arid and semi-arid areas of Mediterranean countries for proper water management under drought conditions. This fact is even more necessary in crops such as almond (Prunus dulcis Mill.), which in the last recent years has been progressively introduced in irrigated areas. An essential aspect to be considered would be the ability to improve fruit-quality parameters when DI strategies are imposed, which can boost the final almond price and ensure the sustainability and competitiveness of this crop. This work examines the effects of sustained deficit irrigation (SDI) on three almond cultivars (Marta, Guara, and Lauranne) on parameters related to almond functionality, aroma and sensory profile, which consequently influence its marketability and consumers acceptance. SDI strategies allowed the improvement of physical parameters such as unit weight, kernel length, kernel thickness or color. Moreover, higher total phenolic compounds, organic acids and sugars were found in SDI almonds. Finally, the highest concentrations of volatile compounds were obtained under SDI, this being a clear advantage in relation to almond flavor. Thus, moderate SDI strategy offered relevant improvements in parameters regarding the marketability, by enhancing the final added value of hydroSOStainable almonds with respect to those cultivated under full irrigation conditions.
\end{abstract}

Keywords: almond quality; sustainability; marketability; semiarid Mediterranean environment; water stress

\section{Introduction}

Water is the most limiting natural resource for sustainable agricultural development in arid and semi-arid areas of Mediterranean and more specifically under climate change scenarios [1]. In this regard, several works have reported the impact of climate change on agriculture [2,3], concluding that crop water demand will increase substantially due to higher evapotranspiration rates, temporal variability of rainfall or heat weaves events [4]. 
Within these scenarios, implementing drought-tolerant crops in irrigated zones and the application of deficit irrigation (DI) strategies are being considered, especially in the last few years [5,6]. Developing water-saving strategies in Mediterranean woody crops involves many considerations relative to environmental constraints, sustainable yields, and product marketability. However, these must be deeply studied, establishing the most profitable strategies to maximize the fruit production, minimizing the irrigation water consumption and maintaining (or even improving) the fruit quality.

Almond (Prunus dulcis Mill.) is the largest tree nut crop, and the world surface dedicated to its cultivation during 2018 amounted to 2,071,884 ha, with Spain being the country with the largest area devoted to this crop, with 657,768 ha, followed by the USA, with 441,107 ha [7]. However, in production terms, relevant differences are found, with 1,872,500 and 339,033 t for the USA and Spain, respectively. Moreover, for the period 2010-2018 in the USA (3500-5608 kg ha-1) and Spain (279-515 kg ha $\left.{ }^{-1}\right)$, the production per area were highly different. In 2018, the Mediterranean basin (Spain, Italy, Greece, Syria, Tunisia, Argelia and Morocco) produced roughly $29 \%$ of the world almond production, with most plantations under rainfed conditions and located in marginal areas. In Spain, the almond cultivation is mainly concentrated in Andalusia (S Spain) (31\% of total area), and since approximately $85 \%$ of almond crops are rainfed, this provokes important fluctuations in productivity [8].

Today, the increase in almond prices from 2014 to 2019, when it reached an average price of $5 €$ per $\mathrm{kg}$ [9], has resulted in an increase of surface devoted to almond cultivation with different techniques [10], explicitly in irrigated areas that were traditionally occupied by other crops (cereals, cotton and sunflower, among others) [11]. This increase in cultivated area under irrigation from 2014 to 2018 amounted to $25 \%$ by using new cultivars [12], which allows to obtain higher yields $\left(>1500 \mathrm{~kg} \mathrm{ha}^{-1}\right)$ than those from traditional rainfed plantations (150-500 $\mathrm{kg} \mathrm{ha}^{-1}$ ) [13].

By taking into consideration the advantage of the positive adaptation of almond to drought scenarios [14,15], and its sharp phenology, many authors have reported the positive responses and opportunities of DI for almond cultivation, obtaining competitive yields under moderate-to-severe water stress situations [16-19].

Recently, a novelty research line, focused on food production under hydro-sustainable strategies (hydroSOStainable products), has been successfully developed [20-22]. This also showed advantages of different Mediterranean crops, with significant improvements in the fruit quality, sensory profile and consumer acceptance in crops such as pistachios [23], olives [24] and almonds [25]. In this context, there is in an interest in those characteristics or parameters of raw almonds related to their marketability that could be affected by DI strategies. In other words, the main limitation of DI implementation is ultimately the yield reduction (in comparison to the potential rate when almond is grown under full-irrigated conditions), affecting the plantation viability and its competitiveness. In this regard, Lipan et al. $[25,26]$ reported relevant results, concluding that some fruit-quality parameters could be improved (or at least not affected) when DI strategies are imposed. If that is the case, these kinds of strategies would encourage the product marketability and the consumer acceptance, allowing a recovering in terms of final price, minimizing the losses when these are analyzed in monetary terms. In addition, many aspects are still not clear, such as if these effects would be similar for the new high-yielding cultivars or the dependence in relation to the irrigation strategy imposed or crop physiological status during the water stress period.

On the other hand, consumer appreciation, and hence, almond marketability, can be determined by a wide number of variables that could be classified into physical and chemical parameters, all of them determining the sensory appreciation and the almond appeal. Raw almonds are mainly composed by fats (44-61\%), proteins (16-23\%) and dietary fiber (11-14\%) and high concentrations of vitamin E $[27,28]$. Despite these being the main compounds of raw almonds, their influence in taste receptors is negligible. In this line, other compounds, more related to flavor properties and sensory and chemical characteristics, can be found. According to Civille et al. [29] the main taste properties of raw almonds are mainly defined by astringency and sweetness degree, and to a lesser extent, the tactile dimensions (almond texture) [30]; this is the highest variability in almond flavor related to odor-active volatiles 
compounds. That is, volatile compounds are responsible of characteristic flavor properties of raw and processed almonds and contribute to their high consumer acceptance [25,31]. In particular, benzaldehyde is one of the main volatiles in bitter almonds, but its presence in sweet almonds is very variable (highly cultivar dependent), and, overall, it is found in very low concentrations [32]. Despite these low concentrations, its presence is responsible of the typical almond flavor and derivates such as marzipan [33].

Considering that the hydroSOStainable almond production could be a key factor for sustainable development in a semiarid Mediterranean environment; the objective of this study was to evaluate the effects of sustained deficit irrigation strategies and almond cultivars on the main physico-chemical parameters involved in nut sensory profile and improvements in marketability.

\section{Material and Methods}

\subsection{Plant Material, Growing Conditions and Experimental Design}

The trial was conducted during 2019 in a commercial orchard of almonds (Prunus dulcis Mill., cos Guara, Marta and Lauranne), grafted onto GN15 rootstock, and located in the Guadalquivir river basin ( $\left.37^{\circ} 30^{\prime} 27.4^{\prime \prime} \mathrm{N} ; 5^{\circ} 55^{\prime} 48.7^{\prime \prime} \mathrm{O}\right)$ (Seville, SW Spain) (Figure 1). The plantation contained seven-year-old almond trees, $8 \times 6 \mathrm{~m}$ spaced and drip irrigated by using two pipelines with emitters of $2.3 \mathrm{~L} \mathrm{~h}^{-1}$. The soil is a silty loam typical Fluvisol [34], more than $2 \mathrm{~m}$ deep, fertile and with an organic matter content of $15.0 \mathrm{~g} \mathrm{~kg}^{-1}$. Roots were located predominately in the first $50 \mathrm{~cm}$ of soil, corresponding to the intended wetting depth, although these exceed more than one meter in depth. The climatology in the study area is attenuated meso-Mediterranean, with an annual reference evapotranspiration rate $\left(\mathrm{ET}_{0}\right)$ of $1400 \mathrm{~mm}$ and an annual rainfall of $540 \mathrm{~mm}$, mainly distributed from October to April. More details about the experimental site can be found in Gutiérrez-Gordillo et al. [35].

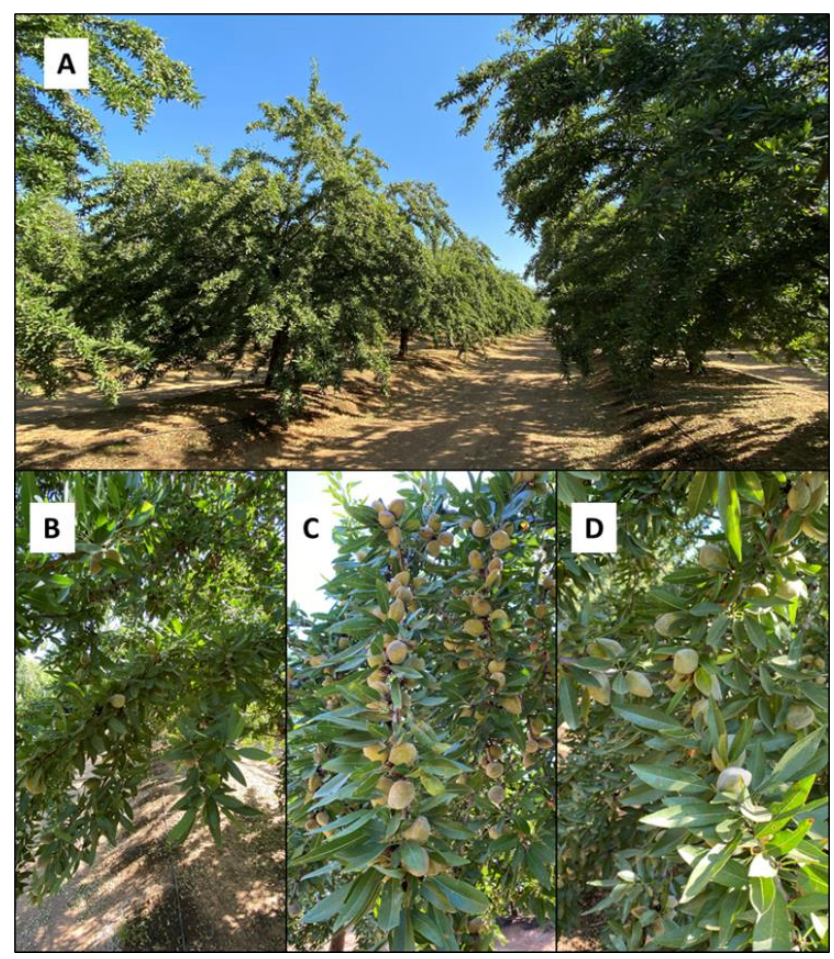

Figure 1. Experimental almond orchard (A) and cvs. Marta (B), Guara (C) and Lauranne (D).

Three irrigation treatments were designed: (i) a full-irrigated treatment (FI), which received $100 \%$ of irrigation requirements (IR) during the irrigation period, and two sustained-deficit irrigation treatments, which received $75 \%\left(\mathrm{SDI}_{75}\right)$ and $65 \%\left(\mathrm{SDI}_{65}\right)$ of IR. Irrigation was applied from April to 
October, the IR being estimated according to the methodology proposed by Allen et al. [36], obtaining the values of $\mathrm{ET}_{0}$ by using a weather station installed in the same experimental orchard (Davis Advance Pro2, Davis Instruments, Valencia, Spain). The local crop coefficients used during the experimental period ranged from 0.4 to 1.2, according to the results obtained by García-Tejero et al. [37].

\subsection{Field Measurements}

Physiological response to different irrigation doses was evaluated throughout measurements of leaf water potential $\left(\Psi_{\text {leaf }}\right)$ in shaded leaves, these readings being taken between 12:00 and13:30 GTM, and on a weekly basis. Measurements of $\Psi_{\text {leaf }}$ were developed by using a pressure chamber (Soil Moisture Equipment Corp., Sta. Barbara, CA, USA), monitoring eight trees per irrigation treatment (two leaves per tree), located in the north side of the tree and being totally mature, fresh and shaded, at $1.5 \mathrm{~m}$ of height. These readings were used to quantify the water stress supported by the crop for each week and the whole kernel-filling period by means of the stress integral $\left(\Psi_{\text {Int }}\right)$, following the methodology proposed by Myers [38] (Equation (1)). This index allows to quantify the effect of water stress provided by the water restriction beyond its temporal distribution, integrating the global stress supported by the crop in comparison to the punctual measurements:

$$
\psi_{\text {Int }}=\left|\sum\left(\psi_{\text {leaf }}^{\text {av }}-\left(\psi_{\text {leaf }}^{\text {max }}\right)\right) \cdot \mathrm{n}\right| .
$$

where $\Psi_{\text {Int }}$ is the stress integral in terms of $\Psi_{\text {leaf }}$ values, $\psi_{\text {leaf }}^{a v}$ is the average leaf water potential for any interval (in our case, for each week), $\psi_{\text {leaf }}^{\text {max }}$ is the maximum value of $\Psi_{\text {leaf }}$ weekly registered, during the experimental period and $\mathrm{n}$ is the days numbers within each interval, in our case $n=7$.

At the end of each season, monitored trees (eight per cultivar and irrigation strategy) were harvested. This process was carried out by using a mechanic vibrator to throw the almond on the ground (previously covered with a plastic mesh). Collected almonds were processed with a mechanic peeling to remove the hull. Finally, once cleaned, almonds were left to air dry and weighed once reached a humidity content around 6\%. Around $3 \mathrm{~kg}$ of in-shell almonds were sent to Miguel Hernández University for quality and sensory analysis, where the main morphological, physical and chemical parameters were analyzed (Figure 2).
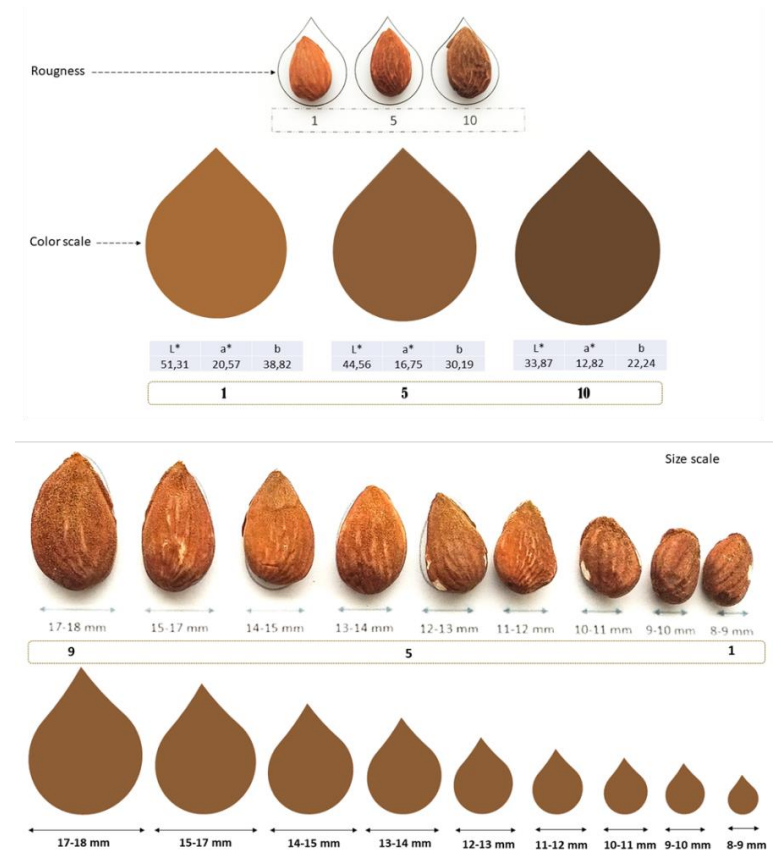

Figure 2. Scales reference used by trained panel to evaluate the almond appearance in this study. 


\subsection{Morphological and Physical Parameters}

The ratio between the mass of in-shell almonds and kernel was calculated from $\sim 1 \mathrm{~kg}$ of nuts per cultivar and irrigation treatment. Additionally, 225 almonds ( 25 samples $\times 3$ varieties $\times 3$ treatments) were randomly selected and analyzed by measuring the weight and size (length, width and thickness) of almonds (both in-shell and kernel) using a digital caliper (Mitutoyo 500-197-20, Kawasaki, Japan) and a scale (Mettler Toledo model AG204, Barcelona, Spain), respectively.

A Minolta Colorimeter CR-300 (Minolta, Osaka, Japan) was used to perform the color measurements in 75 kernels per each variety. This colorimeter uses a $\mathrm{D}_{65}$ illuminant and a $10^{\circ}$ observer as references. The color was provided as CIEL* $a^{*} b^{*}$ coordinates defining the color in a three-dimensional space and it was expressed in three numerical values, which includes $L^{*}$ for the lightness $\left(L^{*}=0\right.$ black; $L^{*}=100$ white), $a^{*}$ for the green-red $\left(a^{*}=\right.$ red; $-a^{*}=$ green) and $b^{*}$ for the blue-yellow components $\left(b^{*}=\right.$ yellow; $-b^{*}=$ blue).

\subsection{Chemical Composition}

\subsubsection{Total Sugars}

Sugars were determined using a high-performance liquid chromatography (HPLC) equipment. The extraction consisted of $1 \mathrm{~g}$ of grinded almond in a Moulinex grinder (AR110830) for $10 \mathrm{~s}$, homogenized with $5 \mathrm{~mL}$ of phosphate buffer with an homogenizer (Ultra Turrax T18 Basic) over $2 \mathrm{~min}$ at $11.3 \mathrm{rpm}$, while the tube was maintained in an ice bath and after it was centrifuged for $20 \mathrm{~min}$ at 15,000 rpm and $4{ }^{\circ} \mathrm{C}$ (Sigma 3-18 K; Sigma Laborzentrifugen, Osterode and Harz, Germany) followed by filtration and injection in the HPLC equipment. Sugar content was determined by using a Supelcogel TM C-610H column $(30 \mathrm{~cm} \times 7.8 \mathrm{~mm}$ ) with a pre-column (Supelguard $5 \mathrm{~cm} \times 4.6 \mathrm{~mm}$; Supelco, Bellefonte, PA, USA) and it was detected by a refractive index detector (RID). Organic acid absorbance was measured at $210 \mathrm{~nm}$ in the same HPLC condition using a diode-array detector (DAD). Analyses were triplicated and results were expressed as $\mathrm{g} \mathrm{kg}^{-1}$ dry weight.

\subsubsection{Volatile Compounds}

For the extraction of the volatile compounds, headspace solid phase microextraction (HS-SPME) was used. Ground almond ( $1 \mathrm{~g})$ was added to a hermetic vial with polypropylene cap and PTFE (polytetrafluoroethylene)/silicone septa, together with $500 \mu \mathrm{L}$ salty water $(12.5 \% \mathrm{NaCl})$ and $2.5 \mu \mathrm{L}$ of 2-acethylthiazole $\left(1000 \mathrm{mg} \mathrm{L}^{-1}\right)$ internal standard, needed for the semi-quantification of the volatile compounds. To simulate the mouth temperature, the vial was heated in a laboratory hot plate up to $50^{\circ} \mathrm{C}$. When the temperature was reached and was stable, a $50 / 30 \mu \mathrm{m}$ Divinylbenzene/Carboxen/Polydimethylsiloxane (DVB/CAR/PDMS) fiber was introduced in the headspace of the vial for $35 \mathrm{~min}$. A gas chromatograph Shimadzu GC-17A (Shimadzu Corporation, Kyoto, Japan) coupled with mass spectrometer (MS) detector Shimadzu QP-5050A were used for isolation and identification of the volatile compounds. The Gas Chromatography-Mass Spectrometry (GC-MS) was equipped with a SLB- $5 \mathrm{~ms}$ Fused Silica Capillary Column of $30 \mathrm{~m} \times 0.25 \mathrm{~mm} \times 0.25 \mu \mathrm{m}$ film thickness, $5 \%$ diphenyl and 95\% dimethyl siloxane (Supelco Analytical). Helium was used as gas carrier at a flow rate of $0.9 \mathrm{~mL} \mathrm{~min}^{-1}$ in a split ratio of 1:5. The oven program was: (a) initial temperature $50{ }^{\circ} \mathrm{C}$, (b) rate of $4.0^{\circ} \mathrm{C} \mathrm{min}-1$ to $130{ }^{\circ} \mathrm{C}$, (c) rate of $10^{\circ} \mathrm{C} \mathrm{min}^{-1}$ from $130{ }^{\circ} \mathrm{C}$ to $180^{\circ} \mathrm{C}$, (d) rate of $20^{\circ} \mathrm{C}$ from $180^{\circ} \mathrm{C}$ to $280^{\circ} \mathrm{C}$. The injector and the detector were held at $250^{\circ} \mathrm{C}$. The identification of the volatile compounds was performed using three methods: (a) retention indices, (b) GC-MS retention times of authentic chemicals and (c) mass spectra compounds were extracted using HS-SPME.

Simultaneously, the quantification of the volatile compounds was done on a gas chromatograph, Shimadzu 2010, with a flame ionization detector (FID). The column and chromatographic conditions were those previously reported for the GC-MS analysis. The injector temperature was $200{ }^{\circ} \mathrm{C}$ and nitrogen was used as carrier gas $\left(1 \mathrm{~mL} \mathrm{~min}^{-1}\right)$. The quantification was obtained from electronic 
integration measurements using flame ionization detection (FID). 2-Acethylthiazole (2.5 $\mu \mathrm{L}$ of $1000 \mathrm{mg} \mathrm{L}^{-1}$ ) was used as internal standard.

\subsection{Descriptive Sensory Analysis}

The descriptive sensory analysis was held by a trained panel with a 10 highly qualified panelists from the Food Quality and Safety Group (Miguel Hernández University of Elche, Orihuela, Alicante, Spain). The descriptive sensory analysis was performed to estimate if the significant differences among treatments were found. Although the panelists were highly trained, having more than $600 \mathrm{~h}$ of experience with different types of food products, three orientation sessions were done prior to almond tasting, where the panelists were trained with reference products for each attribute according to the lexicon previously described by Lipan et al. [25]. The samples were served in odor-free $30 \mathrm{~mL}$ covered plastic cup and randomly coded with three digits. To clean the palate between samples, water and unsalted crackers were served. The descriptive test was performed in a special tasting room with individual booths (controlled temperature of $21 \pm 1{ }^{\circ} \mathrm{C}$ and combined natural/artificial light), and to collect panelists' evaluations, ballot charts were used. The samples were presented based on a randomized block design to avoid biases. Numerical scale from 0 to 10 was used by the panelists to quantify the intensity of the almond attributes, where 0 represents no intensity and 10 extremely strong with a 0.5 increment (Figure 2).

\subsection{Statistical Analysis}

The stress integral of $\Psi_{\text {leaf }}$ and yield were analyzed by Sigma Plot statistical software (version 12.5, Systat Software, Inc., San Jose, CA, USA). Initially, a descriptive analysis for each treatment and cultivar was done, applying a Levene's test to check the variance homogeneity of the whole of data. Once completed, a one-way analysis of variance (ANOVA) was performed to determine whether there were statistical differences $(p<0.05)$ between irrigation treatments and within each cultivar, applying a Tukey's test to find the differences among them.

Relating to the quality and sensorial parameters, a two-way analysis of variance (ANOVA) was performed, with the cultivar and irrigation being the two factors. Moreover, a Tukey's multiple range test was carried out to establish the means that were significantly different from each other. XLSTAT Premium 2016 (Addinsoft, New York, NY, USA) was used to perform statistically significant differences, with a significant level $p<0.05$.

\section{Results and Discussion}

\subsection{Irrigation Doses, Crop Physiological and Yield Response}

Table 1 summarizes the climatic conditions throughout the experiment with cumulative rainfall and crop evapotranspiration $\left(\mathrm{ET}_{\mathrm{C}}\right)$ of 85 and $840 \mathrm{~mm}$, respectively. According to the registered data, the water irrigation amount for $\mathrm{FI}, \mathrm{SDI}_{75}$ and $\mathrm{SDI}_{65}$ was 770,574 and $516 \mathrm{~mm}$, respectively.

The irrigation doses imposed different physiological responses and yield reductions were observed in the SDI strategies with respect to FI (Table 2). The $c v$. Marta reported higher values of $\Psi_{\text {Int }}$ in $\mathrm{SDI}_{65}$ (197 MPa) compared to that registered in FI (179 MPa), with intermediate values for SDI 75 (188 MPa). These differences were even more pronounced for $c v$. Guara with $\Psi_{\text {Int }}$ values in SDI treatments ( $\sim 210 \mathrm{MPa})$ significantly higher than in FI (194 MPa). Finally, $c v$. Lauranne did not register variations among treatments for $\Psi_{\text {Int }}$ with values of $194 \mathrm{MPa}$. 
Table 1. Monthly average values of weather parameters and irrigation doses during the study period.

\begin{tabular}{cccccccc}
\hline Parameters & April & May & June & July & August & September & October \\
\hline $\mathrm{T}_{\max }\left({ }^{\circ} \mathrm{C}\right)$ & 22.2 & 30.4 & 31.3 & 34.5 & 36.5 & 32.4 & 27.6 \\
$\mathrm{~T}_{\min }\left({ }^{\circ} \mathrm{C}\right)$ & 7.2 & 12.2 & 17.5 & 17.9 & 17.9 & 16.3 & 11.7 \\
$\mathrm{~T}_{\mathrm{av}}\left({ }^{\circ} \mathrm{C}\right)$ & 19.8 & 21.5 & 22.7 & 25.8 & 26.9 & 23.8 & 18.9 \\
$\mathrm{RH}_{\max }(\%)$ & 97.8 & 85.2 & 83.2 & 84.0 & 77.2 & 81.9 & 90.7 \\
$\mathrm{RH}_{\min }(\%)$ & 39.8 & 23.3 & 23.4 & 25.3 & 18.7 & 27.6 & 32.9 \\
$\mathrm{RH}_{\mathrm{av}}(\%)$ & 72.2 & 52.3 & 51.4 & 55.4 & 45.9 & 54.4 & 63.2 \\
$\left.\mathrm{Rad}_{(\mathrm{MJ} \mathrm{m}}-2\right)$ & 1.9 & 2.1 & 2.1 & 2.9 & 0.8 & 0.9 & 0.7 \\
$\mathrm{Rainfall}_{(\mathrm{mm})}$ & 71.2 & 0.0 & 0.0 & 0.0 & 0.0 & 3.4 & 10.4 \\
$\mathrm{ET}_{\mathrm{o}}(\mathrm{mm})$ & 111.0 & 198.0 & 202.9 & 238.7 & 170.1 & 121.0 & 76.4 \\
$\mathrm{ET}_{\mathrm{C}}(\mathrm{mm})$ & 44 & 119 & 135 & 215 & 179 & 97 & 46 \\
& & & & Irrigation $(\mathrm{mm})$ & & \\
$\mathrm{FI}$ & 25 & 115 & 140 & 210 & 170 & 80 & 30 \\
$\mathrm{SDI}_{75}$ & 18 & 85 & 104 & 157 & 127 & 61 & 22 \\
$\mathrm{SDI}_{65}$ & 16 & 77 & 95 & 141 & 114 & 53 & 20
\end{tabular}

$\mathrm{T}_{\max }, \mathrm{T}_{\min }, \mathrm{T}_{\mathrm{av}}$, maximum, minimum and average air temperature; $\mathrm{RH}_{\max }, \mathrm{RH}_{\min }, \mathrm{RH}_{\mathrm{av}}$, maximum, minimum and average relative humidity; $\mathrm{Rad}$, solar radiation; $\mathrm{ET}_{0}$, reference evapotranspiration; $\mathrm{ET}_{\mathrm{C}}$, crop evapotranspiration rate; $\mathrm{FI}, \mathrm{SDI}_{75}, \mathrm{SDI}_{65}$, full-irrigated and sustained-deficit irrigation at 75 and $65 \%$ of irrigation requirements, respectively.

Table 2. Integral stress $\left(\Psi_{\text {Int }}\right)$ values and almond yield for the different cultivars and irrigation treatments.

\begin{tabular}{cccc}
\hline & FI & SDI $_{75}$ & SDI $_{65}$ \\
\hline Cultivar & $\Psi_{\text {Int }}($ MPa day $)$ \\
\hline Marta & $179 \mathrm{~b}$ & $188 \mathrm{ab}$ & $197 \mathrm{a}$ \\
Guara & $194 \mathrm{~b}$ & $209 \mathrm{a}$ & $210 \mathrm{a}$ \\
Lauranne & $194 \mathrm{a}$ & $198 \mathrm{a}$ & $191 \mathrm{a}$ \\
\hline \multicolumn{4}{c}{ Almond yield $\left(\mathrm{kg} \mathrm{ha}^{-1}\right)$} \\
\hline Marta & $2218 \mathrm{a}$ & $2208 \mathrm{a}$ & $2243 \mathrm{a}$ \\
Guara & $2254 \mathrm{a}$ & $2081 \mathrm{ab}$ & $1872 \mathrm{~b}$ \\
Lauranne & $2325 \mathrm{a}$ & $2104 \mathrm{a}$ & $2195 \mathrm{a}$ \\
\hline
\end{tabular}

Values (average of eight replications; $\mathrm{n}=8$ ) within a same row, and followed by different letters, show significant differences between treatments and within each cultivar, according to Tukey's test $(p<0.05)$. FI, SDI 75 and SDI 65 , full-irrigated and sustained-deficit irrigation at 75 and $65 \%$ of irrigation requirements, respectively.

In line with the physiological pattern previously described, the studied cultivars also presented yield reductions. In this regard, cvs. such as Marta and Lauranne did not showed significant variations among treatments, while $c v$. Guara was reduced about 8 and $17 \%$ in $\mathrm{SDI}_{75}$ and $\mathrm{SDI}_{65}$, respectively (Table 2).

Taking into consideration the obtained results, the water stress promoted different physiological and yield responses depending on the studied cultivar. In this regard, Gomes-Laranjo et al. [39] also reported different physiological responses of almond cultivars when they were subjected to deficit-irrigation strategies, concluding that $c v$. Lauranne would be less sensitive to irrigation restrictions than other cultivars. More recently, Gutiérrez-Gordillo et al. [17] revealed that $c v$. Marta evidenced a stronger stomatal control as compared to cvs. Guara and Lauranne, when subjected to regulated deficit-irrigation strategies. On the contrary, $c v$. Guara would show a minor conservative behavior, being able to maximize the gas-exchange rates when subjected to water restriction.

However, as observed in the present study, Guara was the most sensitive cultivar growth under SDI conditions. This point is especially remarkable considering that this cultivar presented very positive responses when water restrictions were applied during the kernel-filling period [40,41]. This means that the final response to water stress would be determined by the effect of water restriction, cultivar and deficit-irrigation strategy. Similar results were also reported by Alegre et al. [42], who obtained higher yield reductions in $c v$. Guara as compared to $c v$. Lauranne, when they were subjected to severe SDI $\left(\sim 2500 \mathrm{~m}^{3} \mathrm{ha}^{-1}\right)$. Moreover, Miarnau et al. [43] suggested that under SDI strategies, with irrigation 
applications around $2000 \mathrm{~m}^{3} \mathrm{ha}^{-1}, \mathrm{cv}$. Marta would be able to reach higher productions $\left(1850 \mathrm{~kg} \mathrm{ha}^{-1}\right)$ than those obtained by $c v$. Guara $\left(1200 \mathrm{~kg} \mathrm{ha}^{-1}\right)$ when using similar irrigation doses. Thus, these results would reinforce the statement that $c v$. Marta would be able to activate a physiological prevention mechanism to mitigate the water stress, leading to a higher yield than $c v$. Guara.

\subsection{Morphological and Physical Parameters}

Table 3 displays the main results related to the effects of irrigation doses and cultivar on the physical and morphological properties of raw almonds. Both irrigation treatments and cultivars offered significant differences on the weight, size and physical parameters. In relation to the almond weight, cv. Marta stood out, comparing to cvs. Guara and Lauranne. More evident were the improvements fixed in the almond weight from $\mathrm{SDI}_{65}$ trees regarding to $\mathrm{SDI}_{75}$ and $\mathrm{FI}$ treatments. These differences were also found in the morphological parameters, with higher values in $\mathrm{SDI}_{65}$ for kernel length, the whole thickness and kernel thickness. As was expected, these morphological differences were even more pronounced between cultivars. Thus, cvs. Marta and Lauranne offered a more lengthened morphology in comparison to $c v$. Guara. In relation to the kernel color coordinates, significant differences between cultivars and treatments were observed. Thus, $\mathrm{SDI}_{75}$ and $\mathrm{SDI}_{65}$ registered higher values of $L^{*}, a^{*}$ and $b^{*}$ that evidenced lighter, redder and yellower almonds than FI and with even greater values of chroma, which means a higher color intensity of samples perceived by humans. Instrumental color was also affected by the cultivar, with Guara being the cultivar with the highest values of $L^{*}, a^{*}, b^{*}$ and chroma, whereas cvs. Lauranne and Marta showed a higher similarity between them for these parameters.

In relation to the interaction between irrigation dose $\times$ cultivar, all the studied parameters reported significant differences. For $c v$. Marta, the most notable effects related to the irrigation doses were found for the almond size, with higher values of kernel thickness and length. Moreover, this cultivar registered lower values of $L^{*}, a^{*}, b^{*}$ and chroma for $\mathrm{SDI}_{65}$, while $\mathrm{SDI}_{75}$ was mainly similar to $\mathrm{FI}$ almonds. More interesting were the irrigation effects in $c v$. Guara with significant improvements in the almond and kernel weight for $\mathrm{SDI}_{65}$ compared to $\mathrm{SDI}_{75}$ and FI. Within this cultivar, $\mathrm{SDI}_{65}$ presented higher values of $L^{*}, b^{*}$ and chroma, while $\mathrm{SDI}_{75}$ generated almonds with a greater hardness and crispiness. Finally, regarding $c v$. Lauranne, higher values of almond weight and color on $\mathrm{SDI}_{65}$ were observed, although the weight improvements were more pronounced in the almond shell. 
Table 3. Morphology and instrumental color of raw almonds as affected by deficit treatment and almond cultivar.

\begin{tabular}{|c|c|c|c|c|c|c|c|c|c|c|c|c|c|c|}
\hline & \multicolumn{3}{|c|}{ Weight (g) } & \multicolumn{6}{|c|}{ Size (mm) } & \multicolumn{5}{|c|}{ Kernel Color Coordinates } \\
\hline & Whole & Kernel & Shell & WL & KL & WW & KW & WT & KT & $L^{*}$ & $a^{*}$ & $\mathbf{b}^{*}$ & $\mathrm{C}$ & Hue \\
\hline Irrigation & $* *$ & $* *$ & $* *$ & NS & $* * *$ & NS & NS & $* * *$ & $* * *$ & $* * *$ & $* * *$ & $* * *$ & $* * *$ & NS \\
\hline Cultivar & $* *$ & $* *$ & $* *$ & $* *$ & $* * *$ & $* * *$ & $* * *$ & $* * *$ & $* * *$ & $* * *$ & $* * *$ & $* * *$ & $* * *$ & NS \\
\hline \multirow{2}{*}{ Irrigation $\times$ Cultivar } & \multicolumn{14}{|c|}{ Tukey Multiple Range Test $\ddagger$} \\
\hline & \multicolumn{14}{|c|}{ Irrigation } \\
\hline FI & $3.19 \mathrm{ab}$ & $1.08 \mathrm{~b}$ & $2.11 \mathrm{ab}$ & 30.7 & $22.2 \mathrm{~b}$ & 21.4 & 13.3 & $15.0 \mathrm{~b}$ & $8.30 \mathrm{a}$ & $45.9 \mathrm{~b}$ & 19.1a & $29.9 \mathrm{~b}$ & $35.6 \mathrm{~b}$ & 60.4 \\
\hline $\mathrm{SDI}_{75}$ & $3.07 \mathrm{~b}$ & $1.08 \mathrm{~b}$ & $1.98 \mathrm{~b}$ & 30.0 & $22.2 \mathrm{~b}$ & 21.5 & 13.1 & $14.9 \mathrm{~b}$ & $8.03 \mathrm{~b}$ & $48.7 \mathrm{a}$ & $18.9 \mathrm{ab}$ & $34.9 \mathrm{a}$ & $39.7 \mathrm{a}$ & 61.3 \\
\hline $\mathrm{SDI}_{65}$ & \multicolumn{14}{|c|}{ Cultivar } \\
\hline$c v$. Marta & $3.49 \mathrm{a}$ & $1.19 \mathrm{a}$ & $2.30 \mathrm{a}$ & $30.2 \mathrm{ab}$ & 23.1a & $20.3 c$ & $12.8 \mathrm{~b}$ & $14.8 \mathrm{~b}$ & $8.34 a$ & $47.3 \mathrm{~b}$ & $17.9 \mathrm{~b}$ & $32.1 \mathrm{~b}$ & $36.8 \mathrm{~b}$ & 60.4 \\
\hline$c v$. Guara & $2.92 \mathrm{~b}$ & $1.07 \mathrm{~b}$ & $1.85 \mathrm{c}$ & $29.8 \mathrm{~b}$ & $21.6 \mathrm{c}$ & $22.7 \mathrm{a}$ & $13.5 \mathrm{a}$ & $15.9 a$ & $8.43 a$ & $49.4 \mathrm{a}$ & $19.2 \mathrm{a}$ & $35.0 \mathrm{a}$ & $40.1 \mathrm{a}$ & 64.1 \\
\hline \multirow[t]{3}{*}{ cv. Lauranne } & $3.22 \mathrm{ab}$ & $1.05 \mathrm{~b}$ & $2.17 \mathrm{~b}$ & $30.9 \mathrm{a}$ & $22.4 \mathrm{~b}$ & $21.5 \mathrm{~b}$ & $13.4 \mathrm{a}$ & $14.6 \mathrm{~b}$ & $7.97 \mathrm{~b}$ & $46.6 \mathrm{~b}$ & 19.1a & $32.2 b$ & $37.5 \mathrm{~b}$ & 58.9 \\
\hline & \multicolumn{14}{|c|}{ Irrigation $\times$ Cultivar } \\
\hline & \multicolumn{14}{|c|}{$c v$. Marta } \\
\hline FI & $3.55 \mathrm{a}$ & $1.21 \mathrm{a}$ & $2.34 \mathrm{a}$ & $29.7 \mathrm{~b}$ & $22.5 \mathrm{abc}$ & $20.0 \mathrm{~d}$ & $12.7 \mathrm{c}$ & $14.3 \mathrm{c}$ & 8.13abcd & $48.5 \mathrm{abc}$ & $18.2 \mathrm{bc}$ & $32.6 \mathrm{bcd}$ & $37.4 \mathrm{bcd}$ & 60.6 \\
\hline $\mathrm{SDI}_{75}$ & $3.47 \mathrm{a}$ & $1.18 \mathrm{a}$ & $2.29 \mathrm{a}$ & $30.2 \mathrm{ab}$ & $23.2 \mathrm{ab}$ & $20.4 \mathrm{~cd}$ & 13.0abc & $14.9 \mathrm{bc}$ & $8.49 \mathrm{abc}$ & $48.2 \mathrm{abc}$ & $18.5 \mathrm{abc}$ & $34.1 \mathrm{abc}$ & $38.9 \mathrm{abc}$ & 61.1 \\
\hline & \multicolumn{14}{|c|}{$c v$. Guara } \\
\hline FI & $2.91 \mathrm{~d}$ & $0.99 \mathrm{~b}$ & $1.92 \mathrm{bc}$ & $30.4 a b$ & $21.6 \mathrm{~cd}$ & $22.7 \mathrm{ab}$ & $13.7 \mathrm{a}$ & $16.0 \mathrm{a}$ & $8.72 \mathrm{a}$ & $47.2 \mathrm{bc}$ & $20.0 \mathrm{a}$ & $30.2 \mathrm{cde}$ & $36.5 \mathrm{cde}$ & 66.1 \\
\hline $\mathrm{SDI}_{75}$ & $2.56 \mathrm{~d}$ & $1.00 \mathrm{~b}$ & $1.56 \mathrm{c}$ & $29.5 \mathrm{~b}$ & $21.2 \mathrm{~d}$ & $22.7 \mathrm{ab}$ & 13.2abc & $15.4 \mathrm{ab}$ & $7.96 \mathrm{~cd}$ & $49.6 \mathrm{ab}$ & 19.1ab & $36.6 \mathrm{ab}$ & $41.3 \mathrm{ab}$ & 62.3 \\
\hline $\mathrm{SDI}_{65}$ & $3.30 \mathrm{~b}$ & $1.22 \mathrm{a}$ & $2.08 \mathrm{~b}$ & $29.6 \mathrm{~b}$ & $22.0 \mathrm{bcd}$ & $22.8 \mathrm{a}$ & $13.6 \mathrm{ab}$ & $16.2 \mathrm{a}$ & $8.6 \mathrm{ab}$ & $51.5 \mathrm{a}$ & $18.6 \mathrm{abc}$ & $38.2 \mathrm{a}$ & $42.5 a$ & 63.9 \\
\hline & \multicolumn{14}{|c|}{ cv. Lauranne } \\
\hline FI & $3.12 \mathrm{c}$ & $1.02 \mathrm{~b}$ & $2.09 \mathrm{~b}$ & $32.1 \mathrm{a}$ & $22.4 \mathrm{bcd}$ & $21.7 \mathrm{abc}$ & $13.4 \mathrm{abc}$ & $14.7 \mathrm{bc}$ & $8.05 \mathrm{bcd}$ & $42.0 \mathrm{~d}$ & 19.0ab & $26.9 \mathrm{e}$ & $33.0 \mathrm{e}$ & 54.5 \\
\hline $\mathrm{SDI}_{75}$ & $3.18 \mathrm{c}$ & $1.05 \mathrm{~b}$ & $2.13 \mathrm{~b}$ & $30.3 \mathrm{ab}$ & $22.1 \mathrm{bcd}$ & $21.5 \mathrm{abc}$ & $13.3 \mathrm{abc}$ & $14.3 \mathrm{~b}$ & $7.63 d$ & $48.2 \mathrm{abc}$ & $19.2 \mathrm{ab}$ & $34.0 \mathrm{abc}$ & 39.0abc & 60.6 \\
\hline $\mathrm{SDI}_{65}$ & $3.38 \mathrm{~b}$ & $1.08 \mathrm{~b}$ & $2.30 \mathrm{a}$ & $30.2 \mathrm{ab}$ & $22.5 \mathrm{abc}$ & $21.3 \mathrm{bcd}$ & 13.4abc & $14.9 \mathrm{bc}$ & $8.22 \mathrm{abcd}$ & $49.5 \mathrm{ab}$ & $19.0 \mathrm{ab}$ & $35.7 \mathrm{ab}$ & $40.5 \mathrm{abc}$ & 61.8 \\
\hline
\end{tabular}

NS, not significant at $p<0.05$; ** and ${ }^{* * *}$ significant at $p<0.01$, and 0.001 , respectively. ${ }^{\ddagger}$ Values (average of 25 replication) followed by the same letter, within the same column and factor, were not significantly different $(p<0.05)$, according to Tukey's least significant difference test. WL, Whole Length; KL, Kernel Length; WW, Whole Width; KW, Kernel Width; WT, Whole Thickness; KT, Kernel Thickness; $L^{*}, a^{*}, b^{*}$, Color coordinates; C, Chroma. FI, SDI $75, \mathrm{SDI}_{65}$, full-irrigated and sustained-deficit irrigation at 75 and $65 \%$ of irrigation requirements, respectively. 


\subsection{Total Sugars and Phenolic Content}

The total sugars (TSC) and total phenolic (TPC) contents are shown in Table 4. High significant effects were observed in response to the studied cultivars and irrigation dose imposed. Regarding the TSC, the highest values were reached in almonds under water stress conditions, with $\mathrm{SDI}_{75}$ and $\mathrm{SDI}_{65}$ having a TSC of 62.9 and $62.2 \mathrm{~g} \mathrm{~kg}^{-1}$, respectively, which increased $\sim 19 \%$ with regard to almonds growth under full-irrigated conditions. The cvs. Guara and Lauranne registered the highest values of sugars with $~ 1.4$-fold higher than $c v$. Marta. Comparing all cultivars and irrigation treatments the highest values were reached by $c v$. Guara under $\operatorname{SDI}_{75}\left(76.1 \mathrm{~g} \mathrm{~kg}^{-1}\right)$, followed by $c v$. Guara under $\mathrm{SDI}_{65}\left(68.4 \mathrm{~g} \mathrm{~kg}^{-1}\right)$ and $c v$. Lauranne under $\mathrm{SDI}_{75}$ and $\mathrm{SDI}_{65}\left(65.1\right.$ and $64.7 \mathrm{~g} \mathrm{~kg}^{-1}$, respectively). Thus, SDI conditions led to higher total contents of sugar in all cultivars as compared to fully irrigated trees. As previously reported, raw almonds contain a variable amount of sugars, highlighting sucrose, glucose and fructose [27], whose concentrations are significantly affected by both water stress and cultivar [26]; and hence, their concentrations can vary depending on the water management applied during the fruit development. The increase of sugars in the fruits under stress circumstances is mainly related to the osmotic adjustment, initiated to adapt the plant to dry and saline stress by accumulation of solutes rich in hydroxyl (-OH) groups (sugars, proline etc.) in the cytoplasm [44] and to the induction of the growth inhibitor abscisic acid, inducing the accumulation of osmotically active compounds, which help to protect the cells from harm [45]. Sugars are key compounds in the basic sweet taste of almonds, this fact being important for consumer acceptance $[25,46]$ and essential in the aroma profile of toasted almonds, because these are precursors of aroma compounds formation during thermal processing [47].

Table 4. Impact of deficit irrigation on total phenolic (TPC) and sugars contents (TSC).

\begin{tabular}{|c|c|c|}
\hline & TSC $\left(\mathrm{g} \mathrm{kg}^{-1}\right)$ & TPC (g GAE kg ${ }^{-1}$ ) \\
\hline & \multicolumn{2}{|c|}{ ANOVA $^{+}$} \\
\hline Irrigation & $* * *$ & $* * *$ \\
\hline Cultivar & $* * *$ & $* * *$ \\
\hline \multirow[t]{2}{*}{ Irrigation $\times$ Cultivar } & $* * *$ & $* * *$ \\
\hline & \multicolumn{2}{|c|}{ Tukey Multiple Range Test $\ddagger$} \\
\hline \multicolumn{3}{|c|}{ Irrigation } \\
\hline FI & $52.6 \mathrm{~b}$ & $2.97 \mathrm{~b}$ \\
\hline $\mathrm{SDI}_{75}$ & $62.9 a$ & $3.81 \mathrm{a}$ \\
\hline $\mathrm{SDI}_{65}$ & $62.2 \mathrm{a}$ & $3.80 \mathrm{a}$ \\
\hline \multicolumn{3}{|c|}{ Cultivar } \\
\hline Marta & $48.5 b$ & $3.40 \mathrm{~b}$ \\
\hline Guara & $65.5 a$ & $3.50 \mathrm{~b}$ \\
\hline Lauranne & $63.7 \mathrm{a}$ & $3.68 \mathrm{a}$ \\
\hline \multicolumn{3}{|c|}{ Irrigation $\times$ Cultivar } \\
\hline \multicolumn{3}{|c|}{ cv. Marta } \\
\hline FI & $44.4 \mathrm{f}$ & $2.79 \mathrm{de}$ \\
\hline $\mathrm{SDI}_{75}$ & $47.6 \mathrm{ef}$ & $3.44 \mathrm{~cd}$ \\
\hline $\mathrm{SDI}_{65}$ & $53.6 \mathrm{~d}$ & $3.98 \mathrm{bc}$ \\
\hline \multicolumn{3}{|c|}{ cv. Guara } \\
\hline FI & $52.1 \mathrm{de}$ & $2.29 \mathrm{e}$ \\
\hline $\mathrm{SDI}_{75}$ & $76.1 \mathrm{a}$ & $3.14 \mathrm{cde}$ \\
\hline $\mathrm{SDI}_{65}$ & $68.4 \mathrm{~b}$ & $5.06 \mathrm{a}$ \\
\hline \multicolumn{3}{|c|}{ cv. Lauranne } \\
\hline FI & $61.3 c$ & $3.82 \mathrm{c}$ \\
\hline $\mathrm{SDI}_{75}$ & $65.1 \mathrm{bc}$ & $4.86 \mathrm{ab}$ \\
\hline $\mathrm{SDI}_{65}$ & $64.7 \mathrm{bc}$ & $2.37 \mathrm{e}$ \\
\hline
\end{tabular}

+ -Analysis of variance test (ANOVA), ${ }^{* * *}$ significant at $p<0.001$; GAE, Gallic Acid Equivalent; $¥$ Values (average of three replications) followed by the same letter, within the same column and factor, were not significantly different $(p>0.05)$, according to Tukey's least significant difference test. FI, $\mathrm{SDI}_{75}, \mathrm{SDI}_{65}$, full-irrigated and sustained-deficit irrigation at 75 and $65 \%$ of irrigation requirements, respectively. 
On the other hand, the total phenolic content (TPC) expressed as gallic acid equivalent (GAE) was significantly raised by the SDI treatments with an increase of $28 \%$ regarding the FI almonds. Additionally, cv. Lauranne registered the highest values ( $\left.3.68 \mathrm{~g} \mathrm{GAE} \mathrm{kg}^{-1}\right)$, followed by $c v$. Guara $\left(3.50 \mathrm{~g} \mathrm{GAE} \mathrm{kg}^{-1}\right)$ and $c v$. Marta ( $3.40 \mathrm{~g} \mathrm{GAE} \mathrm{kg}^{-1}$ ), proving the cultivar effect for the TPC. Focusing on the interaction between the irrigation dose and cultivar, the highest TPC values were reached by $c v$. Guara in $\mathrm{SDI}_{65}$ and cv. Lauranne in $\mathrm{SDI}_{75}$ conditions (5.06 $\mathrm{g} \mathrm{GAE} \mathrm{kg}^{-1}$ and $4.86 \mathrm{~g} \mathrm{GAE} \mathrm{kg}^{-1}$, respectively), being the lowest values obtained by $c v s$. Marta and Guara under FI ( 2.79 and $\left.2.29 \mathrm{~g} \mathrm{GAE} \mathrm{kg}^{-1}\right)$ and $c v$. Lauranne under $\mathrm{SDI}_{65}$ conditions $\left(2.37 \mathrm{~g} \mathrm{GAE} \mathrm{kg}^{-1}\right)$. These results agreed with the study by Lipan et al., who found a positive correlation between TPC and water stress in almonds [31]. Moreover, Horner [48] reported that water stress in trees generates an increase in phenolic compounds precursors (free phenylalanine) and their synthesis could be more sensitive in moderate water stress circumstances.

Overall, the water stress in plants decrease the turgor pressure, increase the ion toxicity and inhibits the photosynthesis [49], which leads to the activation of the antioxidant defense system to deal with reactive oxygen species (ROS). The trigger of many defense mechanisms, including the increase in antioxidants to enhance plant tolerance to water stress is mainly done by plant phytohormones [49]. Almond polyphenols are mostly found in skin and are responsible of the kernel color and astringency [50]. In this line, Monagas et al. [51] identified flavonol monomers as well as oligomers up to seven units as the most abundant type of flavonoids in almond skin; moreover, the intensity of the astringency depended on the polymerization degree [52].

\subsection{Volatile Compounds}

Using NIST libraries and Kovats Index values (REF), a total of 35 volatile compounds were identified and presented in Table 5, together with their retention times, retention indices, and their odor descriptors. These include 10 alcohols, 13 alkanes, five terpenes, four aldehydes, one ketone, one acid and one ester. Significant differences $(p<0.001)$ were promoted by the effect of both irrigation and cultivar (Table 6) factors, with the highest values for V2 and V16 to V34 under SDI 65 treatment, whereas V4-V9, V12, V14, V15, V17 and V35 reached the highest values under SDI 75 treatment. According to this and attending to the sum (total volatile compounds content), $\mathrm{SDI}_{75}$ was able to increase the volatile compounds. By contrast, the $\mathrm{SDI}_{65}$ strategy reflected a reduction in the whole amount, which is significantly lower than that obtained under moderate $\mathrm{SDI}_{75}$, which confirms the theory about the quadratic equation of Horner [48], who reported a reduction in fruit chemical compounds when the stress threshold is exceeded. Additionally, differences among cultivars were also found, with Marta and Guara being the cultivars that registered the highest values of the total volatiles. However, focusing the attention in the most abundant compounds (V15 and V17), the highest amounts of benzaldehyde (V15) were registered for $\mathrm{SDI}_{75}$ (in terms of irrigation treatment) and Guara (in terms of cultivar) (Table 6). Regarding to pentamethyl heptane, which might be a degradation product of fatty acids, the highest amounts were found for the SDI strategies and $c v$. Marta.

Regarding the interaction irrigation $\times$ cultivar the highest contents of benzaldehyde were reached by cos. Marta and Guara both under $\mathrm{RDI}_{75}$. For the case of pentamethyl heptane the highest values were found for $c v$. Marta under $\mathrm{SDI}_{75}, c v$. Guara under FI, and $c v$. Lauranne under $\mathrm{SDI}_{65}$. Finally, and considering the total volatiles, the highest values were registered by $c v$. Marta under $\mathrm{RDI}_{75}$, followed by $c v$. Guara under FI and $c v$. Lauranne under $\mathrm{SDI}_{65}$.

Alcohols were the most abundant volatile compounds found in the present experiment. In this line, Kwak et al. [32] reported that alcohols are the main volatiles in raw almonds (cv. Nonpareil) and are released by enzymatic reactions. These compounds might contribute to the typical raw sweet aroma of almonds and an increase in its concentration may improve consumer acceptance [31,32]. In the present study, the highest content of alcohols was reached by the SDI 75 treatment $\left(296 \mu \mathrm{g} \mathrm{kg}^{-1}\right)$, followed by FI $\left(288 \mu \mathrm{g} \mathrm{kg}^{-1}\right)$ and it was reduced by $\operatorname{SDI}_{65}\left(243 \mu \mathrm{g} \mathrm{kg}^{-1}\right)$. Regarding the cultivar effect, cv. Lauranne recorded the highest values of alcohols followed by cvs. Marta and Guara with 310, 296 and $220 \mu \mathrm{g} \mathrm{kg}^{-1}$, respectively. 
Table 5. Volatile compounds profile in raw studied almonds cultivars, retention index and main odor and aroma descriptors.

\begin{tabular}{|c|c|c|c|c|c|c|}
\hline \multirow{2}{*}{ Code } & \multirow{2}{*}{ Compound } & \multirow{2}{*}{ Chemical Family } & \multirow{2}{*}{ RT (min) } & \multicolumn{2}{|c|}{ Retention Index ${ }^{\dagger}$} & \multirow{2}{*}{ Odor Descriptor } \\
\hline & & & & Experimental & Literature $\ddagger$ & \\
\hline V1 & 3-Methyl-2-butanol & Alcohol & 1.65 & 699 & 700 & $\begin{array}{l}\text { Musty, alcoholic, vegetable, cider, } \\
\text { cocoa, cheesy }{ }^{1}\end{array}$ \\
\hline V2 & Acetoin & Ketone & 1.765 & 702 & 707 & $\begin{array}{l}\text { Sweet, buttery, creamy, dairy, } \\
\text { milky, fatty }{ }^{1}\end{array}$ \\
\hline V3 & Acetic acid ${ }^{¥}$ & Acid & 2.083 & 717 & 630 & Pungent, acidic, cheesy, vinegar ${ }^{1}$ \\
\hline V4 & 3-Hexenol & Alcohol & 2.548 & 739 & 746 & $\begin{array}{l}\text { Green, leafy, floral, petal, oily, } \\
\text { earthy }{ }^{1}\end{array}$ \\
\hline V5 & 1-Pentanol & Alcohol & 3.053 & 764 & 762 & $\begin{array}{l}\text { Pungent, fermented, bready, yeasty, } \\
\text { winey, solvent-like }\end{array}$ \\
\hline V6 & 2-Pentenol & Alcohol & 3.097 & 767 & 767 & Fermented, ripe banana, apple ${ }^{1}$ \\
\hline V7 & $\alpha$-Octene & Alkene & 3.677 & 794 & 788 & \\
\hline V8 & Octane & Alkane & 3.805 & 800 & 800 & \\
\hline V9 & Hexanal & Aldehyde & 3.905 & 805 & 804 & $\begin{array}{l}\text { Fresh green fatty aldehydic grassy } \\
\text { leafy fruity sweaty }{ }^{1}\end{array}$ \\
\hline V10 & (2E)-2-Octene & Alkene & 4.057 & 812 & 815 & \\
\hline V11 & (2E)-2-Hexenal & Aldehyde & 4.457 & 831 & 825 & $\begin{array}{l}\text { Green, banana, aldehydic, fatty, } \\
\text { cheesy }^{1}\end{array}$ \\
\hline V12 & Nonane & Alkane & 5.903 & 900 & 900 & Gasoline $^{1}$ \\
\hline V13 & $\alpha$-Pinene & Terpene & 6.924 & 934 & 933 & $\begin{array}{l}\text { Sharp, warm, resinous, fresh, } \\
\text { pine }^{1}\end{array}$ \\
\hline V14 & Citronellene & Terpene & 7.241 & 945 & 945 & Citronellol, herbal, citrus, terpenic \\
\hline V15 & Benzaldehyde & Aldehyde & 7.963 & 970 & 967 & $\begin{array}{l}\text { Almond, fruity, powdery, nutty, } \\
\text { cherry, sweet, bitter }{ }^{1}\end{array}$ \\
\hline V16 & Heptanol & Alcohol & 8.435 & 986 & 977 & $\begin{array}{c}\text { Musty, leafy green, fruity, apple, } \\
\text { banana and nutty and fatty notes }{ }^{1}\end{array}$ \\
\hline V17 & $\begin{array}{l}\text { 2,2,4,6,6-Pentamethyl } \\
\text { heptane }^{¥}\end{array}$ & Alkane & 8.627 & 991 & 997 & \\
\hline V18 & Decane & Alkane & 8.87 & 1000 & 1000 & \\
\hline V19 & 2-Octanol & Alcohol & 9.192 & 1010 & 1010 & $\begin{array}{l}\text { Fresh, spicy, green, woody, herbal } \\
\text { earthy }{ }^{1}\end{array}$ \\
\hline V20 & Limonene & Terpene & 9.97 & 1032 & 1034 & Citrus, orange, sweet, fresh, peely ${ }^{1}$ \\
\hline V21 & 2-Ethyl-hexanol & Alcohol & 10.044 & 1034 & 1030 & Citrus, fresh, floral oily sweet ${ }^{1}$ \\
\hline V22 & 3,5,5-Trimethyl-hexanol & Alcohol & 10.513 & 1048 & 1048 & $\begin{array}{l}\text { Green, floral, camphoreous, woody, } \\
\text { melon, berry. }\end{array}$ \\
\hline V23 & Butanoate & Ester & 10.839 & 1058 & 1054 & Fruity, pineapple odor ${ }^{1}$ \\
\hline V24 & Undecane & Alkane & 12.333 & 1100 & 1100 & $\begin{array}{l}\text { Waxy, fruity, creamy, fatty, orris, } \\
\text { floral, pineapple }\end{array}$ \\
\hline V25 & Linalool & Terpene & 12.525 & 1106 & 1106 & Citrus, orange, floral, terpy, rose ${ }^{1}$ \\
\hline V26 & Nonanal & Aldehyde & 12.862 & 1115 & 1107 & $\begin{array}{l}\text { Waxy, aldehydic, citrus, green } \\
\text { lemon peel, orange peel }{ }^{1}\end{array}$ \\
\hline V27 & Octyl-formate & Alkane & 13.683 & 1136 & 1128 & Fruity, rose, orange, waxy, cumber \\
\hline V28 & 1-Nonanol & Alcohol & 15.425 & 1185 & 1181 & $\begin{array}{l}\text { Fresh, clean, fatty, floral, rose, } \\
\text { orange, dusty, wet, oily }{ }^{1}\end{array}$ \\
\hline V29 & (2Z)-2-Dodecene & Alkene & 15.701 & 1193 & 1193 & Pleasant odor $^{2}$ \\
\hline V30 & Dodecane & Alkane & 15.979 & 1200 & 1200 & \\
\hline V31 & 3,7-Dimethyl-1-octanol ${ }^{¥}$ & Alcohol & 16.283 & 1209 & 1190 & $\begin{array}{l}\text { Aldehydic citrus, rosy and green } \\
\text { woody notes }{ }^{1}\end{array}$ \\
\hline V32 & Tridecane & Alkane & 19.525 & 1301 & 1300 & \\
\hline V33 & Tetradecane & Alkane & 22.5 & 1401 & 1400 & Mild waxy ${ }^{1}$ \\
\hline V34 & Pentadecanol & Alcohol & 27.993 & 1770 & 1772 & Mild alcohol odor ${ }^{2}$ \\
\hline V35 & Geranyl linalool & Terpene & 29.933 & 2039 & 2034 & Mild floral rose balsam ${ }^{1}$ \\
\hline
\end{tabular}

${ }^{¥}$ tentatively identified (identification only based on spectral database); ${ }^{\dagger}$ RT, retention time; ${ }^{\ddagger}$ NIST [53];

${ }^{1}$ Company [54]; ${ }^{2}$ NCBI [55]. 
Table 6. Volatile compounds are based on the use of 2-acethyl thiazole as internal standard in raw almonds.

\begin{tabular}{|c|c|c|c|c|c|c|c|c|c|c|c|c|c|c|c|c|c|c|}
\hline \multirow{4}{*}{ Code } & \multirow{4}{*}{ Irrigation } & \multicolumn{2}{|c|}{ ANOVA $^{+}$} & \multicolumn{3}{|c|}{ Irrigation } & \multicolumn{3}{|c|}{ Cultivar } & \multicolumn{9}{|c|}{ Irrigation $\times$ Cultivar } \\
\hline & & & & \multirow{2}{*}{$\mathrm{F}_{\mathrm{I}}$} & \multirow{2}{*}{$\mathrm{RDI}_{75}$} & \multirow{2}{*}{$\mathrm{RDI}_{65}$} & \multirow{2}{*}{ Marta } & \multirow{2}{*}{ Guara } & \multirow{2}{*}{ Lauranne } & \multicolumn{3}{|c|}{ cv. Marta } & \multicolumn{3}{|c|}{ cv. Guara } & \multicolumn{3}{|c|}{$c v$. Lauranne } \\
\hline & & Cultivar & Irrigation $\times$ Cultivar & & & & & & & FI & $\mathrm{SDI}_{75}$ & $\mathrm{SDI}_{65}$ & FI & $\mathrm{SDI}_{75}$ & $\mathrm{SDI}_{65}$ & FI & $\mathrm{SDI}_{75}$ & $\mathrm{SDI}_{65}$ \\
\hline & & Cuitivar & Irrigation $\times$ Cultivar & \multicolumn{15}{|c|}{$\left(\mu \mathrm{g} \mathrm{kg}^{-1}\right)$} \\
\hline V1 & $* * *$ & $* * *$ & $* * *$ & $17.2 \mathrm{a}$ & $6.07 \mathrm{~b}$ & $5.19 \mathrm{~b}$ & $3.25 c$ & $8.43 \mathrm{~b}$ & $16.7 \mathrm{a}$ & $4.08 \mathrm{~d}$ & $4.14 \mathrm{~d}$ & $1.54 \mathrm{~d}$ & $21.2 \mathrm{~b}$ & $2.04 \mathrm{~d}$ & $2.01 \mathrm{~d}$ & $26.2 a$ & $12.0 \mathrm{c}$ & $12.0 \mathrm{c}$ \\
\hline V2 & $* * *$ & $* * *$ & $* * *$ & $6.61 \mathrm{c}$ & $9.71 \mathrm{~b}$ & $11.2 \mathrm{a}$ & $9.17 \mathrm{~b}$ & $4.34 c$ & $14.0 \mathrm{a}$ & $7.53 \mathrm{~cd}$ & $14.3 \mathrm{~b}$ & 5.71de & $3.86 \mathrm{e}$ & $5.94 \mathrm{cde}$ & $3.23 \mathrm{e}$ & $8.44 \mathrm{~cd}$ & $8.91 \mathrm{c}$ & $24.7 \mathrm{a}$ \\
\hline V3 & $* * *$ & $* * *$ & $* * *$ & $15.4 \mathrm{a}$ & $4.11 \mathrm{~b}$ & $3.18 \mathrm{~b}$ & $3.75 b$ & $4.79 b$ & $14.2 \mathrm{a}$ & $2.32 \mathrm{c}$ & $5.33 \mathrm{bc}$ & $3.60 \mathrm{c}$ & $8.35 \mathrm{~b}$ & $3.58 c$ & $2.43 \mathrm{c}$ & $35.6 \mathrm{a}$ & $3.43 c$ & $3.53 c$ \\
\hline V4 & $* * *$ & $* * *$ & $* * *$ & $1.89 \mathrm{~b}$ & $3.24 a$ & $1.84 \mathrm{~b}$ & $3.36 a$ & $1.29 \mathrm{c}$ & $2.32 \mathrm{~b}$ & $2.45 a$ & $5.76 \mathrm{a}$ & $1.88 \mathrm{~d}$ & $1.54 \mathrm{~d}$ & $1.35 \mathrm{c}$ & $0.97 \mathrm{~d}$ & $1.67 \mathrm{ab}$ & $2.61 \mathrm{bc}$ & $2.67 a b c$ \\
\hline V5 & $* * *$ & $* * *$ & $* * *$ & $109 a$ & $119 a$ & $73.2 \mathrm{~b}$ & $117 \mathrm{a}$ & $59.5 \mathrm{~b}$ & $124 a$ & $149 a$ & $151 \mathrm{a}$ & $52.1 \mathrm{~d}$ & $40.7 \mathrm{~d}$ & $94.9 \mathrm{c}$ & $42.8 \mathrm{~d}$ & $136 a b$ & $111 \mathrm{bc}$ & $125 \mathrm{abc}$ \\
\hline V6 & $* * *$ & $* * *$ & $* * *$ & $35.4 \mathrm{~b}$ & $51.4 a$ & $22.9 \mathrm{c}$ & $51.4 a$ & $22.7 \mathrm{c}$ & $35.6 \mathrm{~b}$ & $35.1 \mathrm{~b}$ & $103 a$ & $16.2 \mathrm{c}$ & $31.4 \mathrm{~b}$ & $19.0 \mathrm{c}$ & $17.6 \mathrm{c}$ & $39.7 \mathrm{~b}$ & $32.2 \mathrm{~b}$ & $35.0 \mathrm{~b}$ \\
\hline V8 & $* * *$ & $* * *$ & $* * *$ & $168 \mathrm{~b}$ & $223 a$ & $141 c$ & $227 a$ & $152 \mathrm{~b}$ & $153 b$ & $228 \mathrm{~b}$ & $305 a$ & 147de & $170 \mathrm{cb}$ & $203 \mathrm{bc}$ & $83.4 \mathrm{f}$ & $107 \mathrm{ef}$ & $161 \mathrm{~cd}$ & $191 \mathrm{bcd}$ \\
\hline V9 & $* * *$ & $* * *$ & $* * *$ & $54.6 \mathrm{a}$ & $50.1 \mathrm{a}$ & $43.2 \mathrm{~b}$ & $56.2 \mathrm{a}$ & $50.4 \mathrm{a}$ & $41.2 \mathrm{~b}$ & 66.6a & $48.3 \mathrm{bc}$ & $53.7 \mathrm{ac}$ & $67.9 \mathrm{a}$ & $58.4 \mathrm{ab}$ & $24.9 \mathrm{e}$ & $29.2 \mathrm{de}$ & $43.6 \mathrm{~cd}$ & $50.9 b c$ \\
\hline V10 & $* * *$ & $* * *$ & $* * *$ & $16.2 \mathrm{~b}$ & $16.4 \mathrm{~b}$ & $30.2 \mathrm{a}$ & $36.2 \mathrm{a}$ & $13.3 \mathrm{~b}$ & $13.3 \mathrm{~b}$ & $28.3 \mathrm{~b}$ & $12.8 \mathrm{cde}$ & $67.5 \mathrm{a}$ & $12.0 \mathrm{de}$ & $19.0 \mathrm{c}$ & $8.83 \mathrm{e}$ & $8.31 \mathrm{e}$ & $17.2 \mathrm{de}$ & $14.4 \mathrm{~cd}$ \\
\hline V11 & $* * *$ & $* * *$ & $* * *$ & $46.1 \mathrm{a}$ & $38.9 \mathrm{~b}$ & $31.2 \mathrm{c}$ & $50.8 \mathrm{a}$ & $38.9 \mathrm{~b}$ & $26.5 c$ & $57.0 \mathrm{a}$ & $52.3 \mathrm{ab}$ & $43.2 \mathrm{bc}$ & $62.5 a$ & $37.7 \mathrm{~cd}$ & $16.4 \mathrm{e}$ & $18.8 \mathrm{e}$ & $26.7 \mathrm{de}$ & $34.0 \mathrm{~cd}$ \\
\hline V12 & $* * *$ & $* * *$ & $* * *$ & $30.8 \mathrm{a}$ & $30.5 a$ & $27.2 \mathrm{~b}$ & $35.1 \mathrm{a}$ & $24.2 \mathrm{c}$ & $29.2 \mathrm{~b}$ & $39.1 \mathrm{ab}$ & $45.0 \mathrm{a}$ & $21.3 \mathrm{c}$ & $33.7 \mathrm{~b}$ & $23.0 \mathrm{c}$ & $15.8 \mathrm{c}$ & $19.6 \mathrm{c}$ & $23.6 \mathrm{c}$ & $44.4 \mathrm{a}$ \\
\hline V13 & $* * *$ & $* * *$ & $* * *$ & $7.85 a$ & $4.80 \mathrm{~b}$ & $3.62 \mathrm{c}$ & $3.82 \mathrm{c}$ & $7.59 a$ & $4.86 \mathrm{~b}$ & $4.88 \mathrm{c}$ & $5.46 \mathrm{bc}$ & $1.13 \mathrm{e}$ & 16.1a & $4.11 \mathrm{~cd}$ & $2.54 \mathrm{de}$ & $2.54 \mathrm{de}$ & $4.84 \mathrm{c}$ & $7.20 \mathrm{~b}$ \\
\hline V14 & $* * *$ & $* * *$ & $* * *$ & $8.42 \mathrm{~b}$ & 9.14a & $8.78 \mathrm{~b}$ & $8.99 \mathrm{a}$ & $7.84 \mathrm{~b}$ & 9.51a & $7.91 \mathrm{c}$ & $12.7 \mathrm{ab}$ & $6.42 \mathrm{c}$ & $10.6 \mathrm{~b}$ & $7.62 \mathrm{c}$ & $5.31 \mathrm{c}$ & $6.76 c$ & $7.16 \mathrm{c}$ & $14.6 \mathrm{a}$ \\
\hline V15 & $* * *$ & $* * *$ & $* * *$ & $292 b$ & $465 a$ & $235 c$ & $419 b$ & $542 \mathrm{a}$ & $31.3 \mathrm{c}$ & $260 \mathrm{~b}$ & $686 a$ & $310 \mathrm{~b}$ & $587 \mathrm{a}$ & $686 a$ & $353 \mathrm{~b}$ & $28.8 \mathrm{c}$ & $21.9 \mathrm{c}$ & $43.3 c$ \\
\hline V16 & $* * *$ & $* * *$ & $* * *$ & $24.5 \mathrm{a}$ & $21.2 \mathrm{~b}$ & $24.0 \mathrm{ab}$ & $20.7 \mathrm{~b}$ & $28.8 \mathrm{a}$ & $20.3 \mathrm{~b}$ & 20.5cde & $24.1 \mathrm{~cd}$ & $17.4 \mathrm{def}$ & $38.2 \mathrm{a}$ & $26.7 b c$ & 21.6cde & 14.9ef & $12.9 \mathrm{f}$ & 33.0ab \\
\hline V17 & $* * *$ & $* * *$ & $* * *$ & $1423 \mathrm{~b}$ & $1482 a$ & 1461ab & $1534 a$ & $1413 b$ & $1418 \mathrm{~b}$ & $1328 \mathrm{~b}$ & 2090a & $1185 \mathrm{~b}$ & $1809 a$ & $1323 b$ & $1108 \mathrm{~b}$ & $1131 \mathrm{~b}$ & $1033 \mathrm{~b}$ & 2091a \\
\hline V18 & $* * *$ & $* * *$ & $* * *$ & $30.4 \mathrm{~b}$ & $28.1 \mathrm{~b}$ & $37.2 \mathrm{a}$ & $27.5 \mathrm{~b}$ & $34.1 \mathrm{a}$ & $34.2 \mathrm{a}$ & $24.5 \mathrm{de}$ & $34.9 b c$ & 23.1e & $40.7 \mathrm{~b}$ & $28.0 \mathrm{cde}$ & $33.6 b c$ & 26.1cde & $21.5 \mathrm{~b}$ & $55.1 \mathrm{a}$ \\
\hline V20 & $* * *$ & $* * *$ & $* * *$ & $22.9 \mathrm{ab}$ & $21.5 \mathrm{~b}$ & $24.5 \mathrm{a}$ & $20.6 \mathrm{~b}$ & $21.3 \mathrm{~b}$ & $27.1 \mathrm{a}$ & $22.5 \mathrm{abc}$ & $21.5 b c$ & $17.7 \mathrm{c}$ & $17.7 \mathrm{c}$ & $17.6 \mathrm{c}$ & $28.6 a$ & $28.6 a$ & $25.5 \mathrm{ab}$ & $27.2 \mathrm{ab}$ \\
\hline V21 & $* * *$ & $* * *$ & $* * *$ & $73.5 \mathrm{~b}$ & $71.4 \mathrm{~b}$ & $83.4 \mathrm{a}$ & $75.4 \mathrm{~b}$ & $73.0 \mathrm{c}$ & $79.9 \mathrm{a}$ & $66.9 \mathrm{c}$ & $95.4 \mathrm{~b}$ & $63.7 \mathrm{c}$ & $96.9 \mathrm{~b}$ & $63.6 c$ & $58.5 \mathrm{c}$ & $56.6 \mathrm{c}$ & $55.3 c$ & $128 \mathrm{a}$ \\
\hline V22 & $* * *$ & $* * *$ & $* * *$ & $56.0 \mathrm{~b}$ & $51.2 \mathrm{~b}$ & $70.5 a$ & $52.3 \mathrm{~b}$ & $56.4 \mathrm{~b}$ & $69.0 \mathrm{a}$ & $47.0 \mathrm{c}$ & $67.1 \mathrm{~b}$ & $42.7 \mathrm{c}$ & $74.3 \mathrm{~b}$ & $48.2 \mathrm{c}$ & $46.7 \mathrm{c}$ & $46.6 \mathrm{c}$ & $38.3 \mathrm{c}$ & $122 a$ \\
\hline V23 & $* * *$ & $* * *$ & $* * *$ & $9.08 \mathrm{~b}$ & $9.18 \mathrm{ab}$ & $9.59 a$ & $9.07 \mathrm{~b}$ & $8.36 \mathrm{~b}$ & $10.4 \mathrm{a}$ & 7.44de & $11.9 \mathrm{bc}$ & 7.88de & $12.8 \mathrm{~b}$ & $9.83 \mathrm{~cd}$ & $2.47 \mathrm{f}$ & 7.03de & $5.81 \mathrm{e}$ & $18.4 \mathrm{a}$ \\
\hline V24 & $* * *$ & $* * *$ & $* * *$ & $12.5 \mathrm{a}$ & $3.95 \mathrm{~b}$ & 11.1a & $2.53 \mathrm{~b}$ & $12.4 \mathrm{a}$ & $12.7 \mathrm{a}$ & $3.27 \mathrm{~cd}$ & $2.61 \mathrm{~cd}$ & $1.70 \mathrm{~d}$ & $7.67 \mathrm{~b}$ & $5.66 \mathrm{bc}$ & $23.7 \mathrm{a}$ & $26.7 \mathrm{a}$ & $3.56 \mathrm{~cd}$ & $7.89 \mathrm{bc}$ \\
\hline V25 & $* * *$ & $* * *$ & $* * *$ & $3.99 \mathrm{~b}$ & $2.54 \mathrm{c}$ & $11.9 \mathrm{a}$ & $3.10 \mathrm{c}$ & $10.7 \mathrm{a}$ & $4.61 \mathrm{~b}$ & $2.41 \mathrm{de}$ & $3.93 \mathrm{~cd}$ & $2.97 \mathrm{cde}$ & $4.34 \mathrm{~cd}$ & $2.41 \mathrm{de}$ & $25.4 a$ & $5.21 \mathrm{bc}$ & $1.29 \mathrm{e}$ & $7.32 \mathrm{~b}$ \\
\hline V26 & $* * *$ & $* * *$ & $* * *$ & $30.1 \mathrm{~b}$ & $23.6 \mathrm{c}$ & $37.8 \mathrm{a}$ & $25.3 \mathrm{c}$ & $30.3 b$ & $35.9 \mathrm{a}$ & 23.1cde & $31.4 \mathrm{c}$ & $21.5 \mathrm{de}$ & $40.9 \mathrm{~b}$ & $22.0 \mathrm{cde}$ & $27.8 \mathrm{~cd}$ & $26.3 \mathrm{cde}$ & $17.3 \mathrm{e}$ & 63.9a \\
\hline V27 & $* * *$ & $* * *$ & $* * *$ & $4.16 \mathrm{~b}$ & $3.86 \mathrm{~b}$ & $5.48 \mathrm{a}$ & $3.73 \mathrm{c}$ & $4.51 \mathrm{~b}$ & $5.27 \mathrm{a}$ & $2.33 \mathrm{~d}$ & $5.75 b$ & $3.12 \mathrm{~cd}$ & $6.17 \mathrm{~b}$ & $3.35 \mathrm{~cd}$ & $4.02 \mathrm{c}$ & $4.00 \mathrm{c}$ & $2.49 \mathrm{~d}$ & 9.31a \\
\hline V28 & $* * *$ & $* * *$ & $* * *$ & $4.89 \mathrm{~b}$ & $3.89 \mathrm{c}$ & $6.35 a$ & $4.04 \mathrm{c}$ & $4.97 \mathrm{~b}$ & $6.12 \mathrm{a}$ & $3.63 \mathrm{~cd}$ & $5.07 \mathrm{c}$ & $3.41 \mathrm{~d}$ & $6.75 \mathrm{~b}$ & $3.60 \mathrm{~cd}$ & $4.54 \mathrm{~cd}$ & $4.28 \mathrm{~cd}$ & $2.98 \mathrm{~d}$ & 11.1a \\
\hline V29 & $* * *$ & $* * *$ & $* * *$ & $3.50 \mathrm{~b}$ & 3.64ab & $3.84 a$ & $2.80 \mathrm{~b}$ & $4.02 \mathrm{a}$ & $4.16 \mathrm{a}$ & $1.42 \mathrm{e}$ & $4.96 \mathrm{~b}$ & 2.01de & $5.67 \mathrm{ab}$ & $3.48 \mathrm{c}$ & $2.92 \mathrm{~cd}$ & $3.41 \mathrm{c}$ & $2.48 \mathrm{cde}$ & $6.58 \mathrm{a}$ \\
\hline V30 & $* * *$ & $* * *$ & $* * *$ & $8.79 a$ & $5.39 \mathrm{~b}$ & 9.49a & $5.10 \mathrm{c}$ & $8.74 \mathrm{~b}$ & 9.83a & $4.67 \mathrm{~cd}$ & $6.95 b c$ & $3.68 \mathrm{~d}$ & $8.85 \mathrm{~b}$ & $4.74 \mathrm{~cd}$ & $12.6 \mathrm{a}$ & $12.8 \mathrm{a}$ & $4.48 \mathrm{~cd}$ & $12.2 \mathrm{a}$ \\
\hline V31 & $* * *$ & $* * *$ & $* * *$ & $8.60 \mathrm{~b}$ & $6.73 c$ & 11.6a & $6.77 \mathrm{c}$ & $8.79 b$ & 11.4a & $6.10 \mathrm{~cd}$ & $9.06 \mathrm{~b}$ & $5.14 \mathrm{~d}$ & $11.0 \mathrm{~b}$ & $6.12 \mathrm{~cd}$ & $9.28 \mathrm{~b}$ & $8.70 \mathrm{bc}$ & $5.00 \mathrm{~d}$ & $20.4 a$ \\
\hline V32 & $* * *$ & $* * *$ & $* * *$ & $9.91 \mathrm{a}$ & $7.69 \mathrm{~b}$ & $10.2 \mathrm{a}$ & $6.32 c$ & $8.99 \mathrm{~b}$ & $12.4 \mathrm{a}$ & $5.29 \mathrm{~d}$ & $9.48 c$ & $4.21 \mathrm{e}$ & $7.84 \mathrm{~cd}$ & $6.17 \mathrm{de}$ & $13.0 \mathrm{~b}$ & $16.6 \mathrm{a}$ & $7.42 \mathrm{~cd}$ & $13.3 \mathrm{~b}$ \\
\hline V33 & $* * *$ & $* * *$ & $* * *$ & $2.94 \mathrm{ab}$ & $2.68 \mathrm{~b}$ & $3.28 \mathrm{a}$ & $3.20 \mathrm{a}$ & $2.40 \mathrm{~b}$ & $3.31 \mathrm{a}$ & $3.12 \mathrm{~b}$ & $4.26 \mathrm{a}$ & $2.22 \mathrm{~cd}$ & $3.10 \mathrm{~b}$ & $1.53 \mathrm{~d}$ & $2.57 \mathrm{bc}$ & $2.60 \mathrm{bc}$ & $2.27 \mathrm{bcd}$ & $5.06 a$ \\
\hline V34 & $* * *$ & $* * *$ & $* * *$ & $1.69 \mathrm{~b}$ & $2.38 \mathrm{a}$ & $2.65 a$ & $2.11 \mathrm{~b}$ & $1.99 \mathrm{~b}$ & $2.61 \mathrm{a}$ & $1.93 \mathrm{c}$ & $3.23 \mathrm{~b}$ & $1.17 \mathrm{~d}$ & $1.80 \mathrm{~cd}$ & $2.69 \mathrm{~b}$ & $1.49 \mathrm{~cd}$ & $1.32 \mathrm{~cd}$ & $1.22 \mathrm{~cd}$ & $5.29 \mathrm{a}$ \\
\hline V35 & $* * *$ & $* * *$ & $* * *$ & $1.09 \mathrm{~b}$ & $1.42 \mathrm{a}$ & $0.97 \mathrm{~b}$ & $1.21 \mathrm{a}$ & $1.10 \mathrm{~b}$ & $1.18 \mathrm{ab}$ & $1.09 \mathrm{~b}$ & $1.79 \mathrm{a}$ & $0.75 c$ & $1.02 \mathrm{bc}$ & $1.19 \mathrm{~b}$ & $1.07 \mathrm{bc}$ & $1.16 \mathrm{~b}$ & $1.27 \mathrm{~b}$ & $1.10 \mathrm{~b}$ \\
\hline$\Sigma$ & $* * *$ & $* * *$ & $* * *$ & $2,636 \mathrm{ab}$ & $2,894 a$ & $2,536 \mathrm{~b}$ & $2,928 \mathrm{a}$ & $2,751 \mathrm{a}$ & $2,387 \mathrm{~b}$ & $2,588 \mathrm{bcd}$ & $3,989 a$ & $2,206 \mathrm{~cd}$ & $3,358 \mathrm{ab}$ & $2,842 \mathrm{bc}$ & $2,054 \mathrm{~d}$ & $1,961 \mathrm{~d}$ & $1,853 \mathrm{~d}$ & $3,347 \mathrm{ab}$ \\
\hline
\end{tabular}


The presence of alkanes, alkenes, acids and aldehydes are mainly related to the oxidative decomposition of the triglyceride and fatty acid components [56]. The oxidation of polyunsaturated fatty acids generates monohydroperoxides, which are precursors of volatile aldehydes such as hexanal, octanal, nonanal and decanal [57]. In the present study, only hexanal, hexenal and nonanal were identified, with values between 112 and $131 \mu^{-g ~ k g}{ }^{-1}$ with the lowest content corresponding to the $\mathrm{SDI}_{65}$ and $\mathrm{SDI}_{75}$ treatments and the highest one to the FI treatment. In this way, Yang et al. [54] when studying the roasted almond shelf life concluded that hexanal and nonanal concentrations should be less than 2140 and $5970 \mu \mathrm{g} \mathrm{kg}^{-1}$, respectively, at the endpoint of shelf life to be suitable for their consumption. Thus, the relatively low experimental contents of hexanal and nonanal are indicative of the freshness of the samples under study.

Benzaldehyde is released from amygdalin, its precursor, by enzymatic hydrolysis, which is a cyanogenic glycoside naturally produced in almond [32]. Moreover, benzaldehyde is a characteristic aroma compound of wild/bitter almonds with a low odor threshold and it is found in a lower concentration in sweet almonds, but it is cultivar dependent $[47,58]$. In this context, the concentration of benzaldehyde in cvs. Vairo and Nonpareil was reported to be below that needed to affect the aroma of the almonds [31,47]. In the present study, the benzaldehyde content for $c v$. Lauranne $\left(31 \mu \mathrm{g} \mathrm{kg}{ }^{-1}\right)$ was similar to that reported for $c v$. Vairo [31]. However, a greater content of this compound was registered by $c v$. Marta $\left(419 \mu \mathrm{g} \mathrm{kg}^{-1}\right)$ and even higher by $c v$. Guara $\left(542 \mu \mathrm{g} \mathrm{kg}^{-1}\right)$. Thus, DI strategies significantly affected the benzaldehyde concentration, which was increased by $\mathrm{SDI}_{75}\left(465 \mu \mathrm{g} \mathrm{kg}^{-1}\right)$, but decreased in more severe conditions of water stress such as SDI $65\left(235 \mu \mathrm{g} \mathrm{kg}^{-1}\right)$ when compared to FI almonds $\left(292 \mu \mathrm{g} \mathrm{kg}^{-1}\right)$. This fact suggests that the benzaldehyde was cultivar and irrigation treatment dependent, which convert it in an alleged marker for cultivar and hydroSOStainable identification.

\subsection{Descriptive Sensory Profile}

Descriptive sensory analysis was conducted to quantify the hypothetical effects of cultivars and irrigation doses on the almond sensory profiles. In this sense, 15 attributes were considered, and in general, significant differences both affected by cultivar and irrigation were found (Table 7). Regarding the DI treatments, panelists found that FI and $\mathrm{SDI}_{75}$ almonds had an intense red-brown color, which agreed with instrumental data, which also showed the highest values for the $a^{*}$ coordinate (FI $=19.1 \mathrm{a}$; $\mathrm{SDI}_{75}=18.9 \mathrm{ab} ; \mathrm{SDI}_{65}=18.2 \mathrm{~b}$ ), indicating that almonds from FI and $\mathrm{SDI}_{75}$ were more reddish than those from $\mathrm{SDI}_{65}$. Regarding the size, even though the instrumental measurements were statistically significant the trained panel did not detect significant differences for these parameters among irrigation treatments. Similar findings were revealed by Lipan et al. [46] and Carbonell-Barrachina et al. [23] on hydroSOStainable almonds and pistachios, respectively, where no significant differences on sensory size were detected.

Regarding the flavor attributes, higher intensity of sweetness, aromatics reminiscent of almond (almond ID) and benzaldehyde-like notes were found for $\mathrm{SDI}_{65}$ almonds; these results proved that these particular almonds are those having the most intense, typical almond flavor. As shown, the benzaldehyde perception by human was in the contrast with the volatile compound concentration, which was higher in the $\mathrm{SDI}_{75}$ in comparison to FI. However, the human perception regarding the sweetness was in agreement with the results of total sugar (Table 4), showing a higher sweetness and sugar content in almonds cultivated under deficit irrigation conditions. 
Table 7. Descriptive sensory analysis of raw almonds as affected by deficit irrigation. Scale used ranged from $0=$ no intensity to $10=$ extremely strong intensity.

\begin{tabular}{|c|c|c|c|c|c|c|c|c|c|c|}
\hline & Outer Color & Size & Roughness & Sweetness & Bitterness & Astringency & Overall Nuts & Almond ID & Benzaldehyde Like & Woody \\
\hline & \multicolumn{10}{|c|}{ ANOVA Test $^{+}$} \\
\hline Irrigation & $* * *$ & NS & $* * *$ & $* * *$ & NS & NS & NS & $* * *$ & $* * *$ & NS \\
\hline Cultivar & $* * *$ & $* * *$ & NS & $* * *$ & NS & NS & $* * *$ & $* * *$ & $* * *$ & NS \\
\hline \multirow[t]{3}{*}{ Irrigation $\times$ Cultivar } & $* * *$ & $* * *$ & $* * *$ & $* * *$ & NS & NS & $* * *$ & $* * *$ & $* * *$ & NS \\
\hline & \multicolumn{10}{|c|}{ Tukey's Multiple Range Test $\ddagger$} \\
\hline & \multicolumn{10}{|c|}{ Irrigation } \\
\hline FI & $3.9 \mathrm{a}$ & 2.8 & $4.2 \mathrm{a}$ & $3.7 \mathrm{~b}$ & 1.2 & 0.5 & 4.5 & $3.4 \mathrm{~b}$ & $2.0 \mathrm{a}$ & 1.9 \\
\hline $\mathrm{SDI}_{75}$ & $1.8 \mathrm{~b}$ & 2.7 & $4.5 \mathrm{a}$ & $3.7 \mathrm{~b}$ & 1.1 & 0.6 & 4.4 & $3.9 \mathrm{ab}$ & $1.8 \mathrm{~b}$ & 1.5 \\
\hline \multirow[t]{2}{*}{$\mathrm{SDI}_{65}$} & $2.0 \mathrm{~b}$ & 2.8 & $2.4 \mathrm{~b}$ & $4.2 \mathrm{a}$ & 1.0 & 0.7 & 4.5 & $4.4 \mathrm{a}$ & $2.1 \mathrm{a}$ & 2.2 \\
\hline & \multicolumn{10}{|c|}{ Cultivar } \\
\hline Marta & $2.2 \mathrm{~b}$ & $3.2 \mathrm{a}$ & 3.7 & $1.9 \mathrm{c}$ & 1.0 & 0.6 & $2.8 \mathrm{c}$ & $1.9 \mathrm{~b}$ & $1.4 \mathrm{~b}$ & 2.2 \\
\hline Guara & $2.5 \mathrm{ab}$ & $2.4 \mathrm{~b}$ & 3.8 & $4.4 \mathrm{~b}$ & 1.5 & 0.7 & $4.7 \mathrm{~b}$ & $4.8 \mathrm{a}$ & $2.9 \mathrm{a}$ & 1.7 \\
\hline \multirow[t]{2}{*}{ Lauranne } & $3.0 \mathrm{a}$ & $2.7 \mathrm{~b}$ & 3.7 & $5.3 \mathrm{a}$ & 0.9 & 0.6 & $5.7 \mathrm{a}$ & $5.2 \mathrm{a}$ & $1.7 \mathrm{~b}$ & 1.6 \\
\hline & \multicolumn{10}{|c|}{ Irrigation $\times$ Cultivar } \\
\hline & \multicolumn{10}{|c|}{$c v$. Marta } \\
\hline FI & $2.1 \mathrm{bc}$ & $3.1 \mathrm{ab}$ & $4.6 \mathrm{ab}$ & $2.1 \mathrm{c}$ & 1.4 & 0.5 & $3.4 \mathrm{bc}$ & $2.3 \mathrm{~cd}$ & $1.7 \mathrm{bc}$ & 1.9 \\
\hline $\mathrm{SDI}_{75}$ & $2.0 \mathrm{bc}$ & $3.5 a$ & $4.4 \mathrm{ab}$ & $1.4 \mathrm{c}$ & 0.6 & 0.4 & $2.6 \mathrm{c}$ & $1.4 \mathrm{~d}$ & $1.1 \mathrm{c}$ & 1.7 \\
\hline $\mathrm{SDI}_{65}$ & $2.4 \mathrm{bc}$ & $3.0 \mathrm{abc}$ & $2.0 \mathrm{c}$ & $2.3 \mathrm{c}$ & 0.6 & 0.8 & $2.5 \mathrm{c}$ & $1.9 \mathrm{~cd}$ & $1.3 \mathrm{c}$ & 3.1 \\
\hline \multicolumn{11}{|c|}{$c v$. Guara } \\
\hline FI & $4.9 \mathrm{a}$ & $2.8 \mathrm{abc}$ & $4.1 \mathrm{ab}$ & $4.0 \mathrm{~b}$ & 1.2 & 0.5 & $4.4 \mathrm{ab}$ & $3.6 \mathrm{bc}$ & $2.4 \mathrm{abc}$ & 2.1 \\
\hline $\mathrm{SDI}_{75}$ & $1.5 \mathrm{bc}$ & $2.1 \mathrm{c}$ & $5.1 \mathrm{a}$ & $4.1 \mathrm{~b}$ & 1.8 & 0.9 & $4.9 \mathrm{ab}$ & $4.8 \mathrm{ab}$ & $2.9 \mathrm{ab}$ & 1.3 \\
\hline $\mathrm{SDI}_{65}$ & $2.16 \mathrm{~b}$ & $2.1 \mathrm{c}$ & $2.1 \mathrm{c}$ & $5.0 \mathrm{ab}$ & 1.6 & 0.8 & $4.8 \mathrm{ab}$ & $5.8 \mathrm{a}$ & $3.5 \mathrm{a}$ & 1.6 \\
\hline \multicolumn{11}{|c|}{$c v$. Lauranne } \\
\hline FI & $4.8 \mathrm{a}$ & $2.5 \mathrm{bc}$ & $4.0 \mathrm{ab}$ & $4.9 \mathrm{ab}$ & 1.0 & 0.5 & $5.5 \mathrm{a}$ & $4.4 \mathrm{ab}$ & $2.1 \mathrm{bc}$ & 1.7 \\
\hline $\mathrm{SDI}_{75}$ & $1.8 \mathrm{bc}$ & $2.3 \mathrm{bc}$ & $4.0 \mathrm{ab}$ & $5.7 \mathrm{a}$ & 0.9 & 0.6 & $5.6 \mathrm{a}$ & $5.4 \mathrm{ab}$ & $1.5 \mathrm{c}$ & 1.5 \\
\hline $\mathrm{SDI}_{65}$ & $2.66 \mathrm{~b}$ & 3.1ab & $3.1 \mathrm{bc}$ & $5.3 \mathrm{ab}$ & 0.6 & 0.6 & $6.0 \mathrm{a}$ & $5.6 \mathrm{ab}$ & $1.5 \mathrm{c}$ & 1.7 \\
\hline
\end{tabular}

${ }^{\dagger} \mathrm{NS}$, not significant at $p<0.05 ; * * *$ significant at $p<0.001$; ${ }^{\ddagger}$ Values (mean of 10 trained panelists) followed by the same letter, within the same column, were not significantly different $(p>0.05)$, according to Tukey's least significant difference test. $\mathrm{FI}_{1} \mathrm{SDI}_{75}$ and $\mathrm{SDI}_{65}$, full-irrigated and sustained-deficit irrigation at 75 and $65 \%$ of irrigation requirements, respectively. Almond ID, aromatics reminiscent of almond. 
Although not many affective studies have been conducted using almond, Lipan et al. [25] concluded that both Spanish and Romanian consumers considered the almond ID (aromatics reminiscent of almond) and sweetness as the main attributes that control the consumer preferences. Moreover, sweetness, flavor, texture and price were the most relevant parameters in the CATA questionnaire when consumers were asked about their buying drivers. Taking into consideration the obtained results in this work, almond ID and sweetness were parameters that reached significant improvements when SDI was imposed, and it would reinforce the statement that water savings strategies in almond crop would help to obtain a final product with a higher acceptance by consumers. Thus, hydroSOStainable almonds with a final added value would allow to recover the economic losses caused by yield reductions, offering a product with a higher competitiveness and marketability (Figure 3), as has been corroborated by authors such as Lipan et al. [46], who concluded that consumers were willing to pay an extra amount of money for the hydroSOStainable almonds.

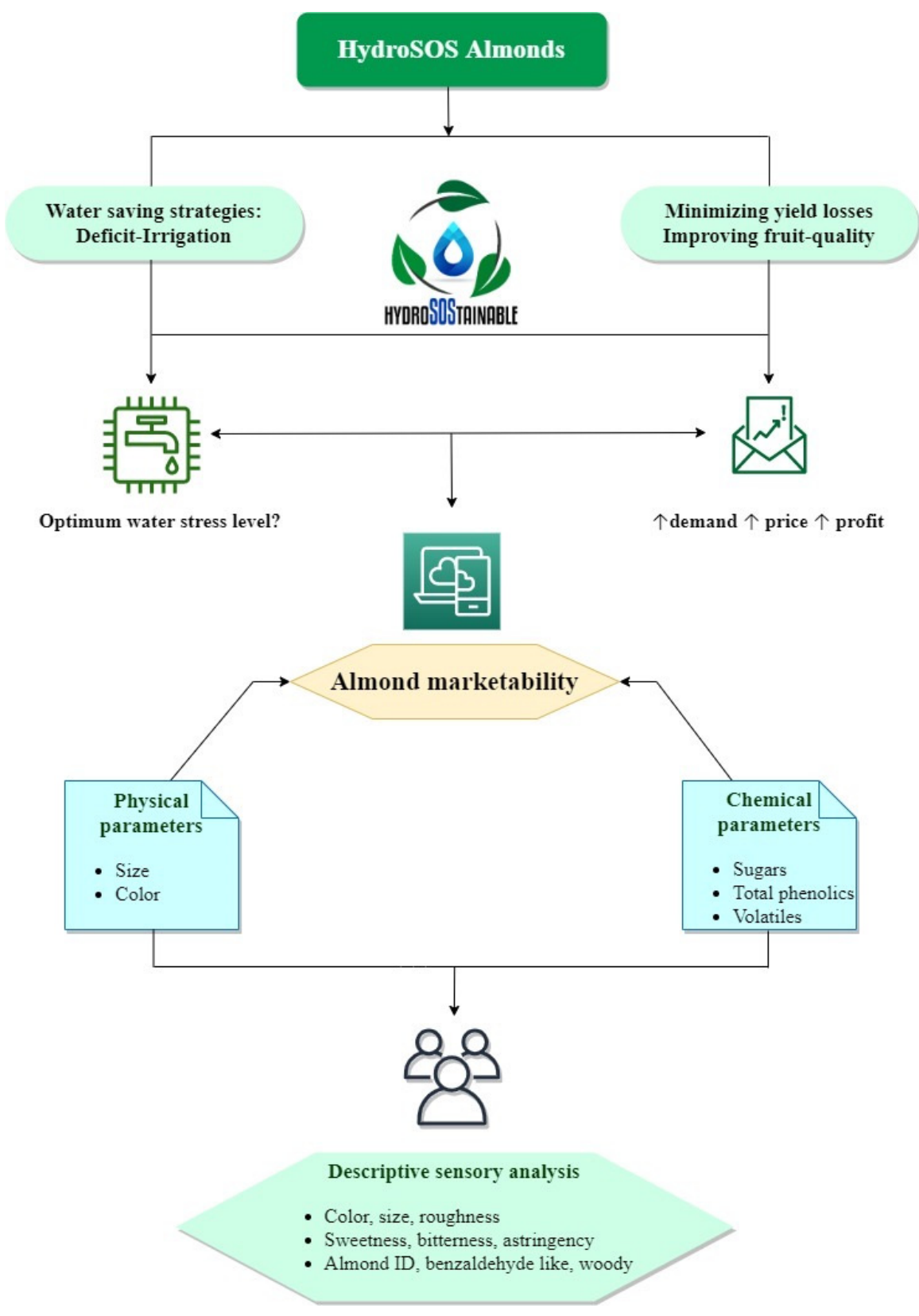

Figure 3. HydroSOStainable almonds: towards an equilibrium among water savings, optimum yields and quality parameters supported by marketability and sensory profile. $\uparrow$, increase. 


\section{Conclusions}

This work highlights the main effects of irrigation in three almond cultivars in terms of the morphological, physicochemical and sensory parameters when this crop is subjected to sustained-deficit irrigation treatments. The findings allow us to conclude that almonds subjected to moderate sustained water stress improved substantially the most important features (sugars, total phenolic content and volatiles) related to the sensory profile and, probably, consumer acceptance. These results supported that all the monitored parameters besides water irrigation amounts are also cultivar-dependent, which determines the need of characterization of each cultivar growth under deficit irrigation conditions. Moreover, this study displayed the advantages of these strategies and opened the possibility of showcasing those hydroSOStainable products that have been obtained within a framework of water scarcity and sustainable use of natural resources. Thus, the findings prove the importance of considering the cultivar effect when these strategies are being imposed, not only in terms of final yield, but also from a nut quality perspective.

Author Contributions: Writing: I.F.G.-T., L.L. and S.G.-G.; Conception or design: I.F.G.-T., L.L. and S.G.-G. Acquisition, analysis, and interpretation of data: I.F.G.-T, L.L., S.G.-G., I.J., F.H. and á.A.C.-B.; Critical revision of the manuscript for important intellectual content: á.A.C.-B., V.H.D.Z. and B.C.R.; Statistical analysis: L.L. and I.F.G.-T.; Reagents/materials/analysis tools contribution: L.L., I.J., F.H., B.C.R. and á.A.C.-B. All authors have read and agree to the published version of the manuscript.

Funding: This work has been partially sponsored by the research project "Impact of climate change and adaptation measures (INNOVA-Climate)" (AVA.AVA2019.051) both co-financed by the European Regional Development Fund (ERDF) within the Operational Programme Andalusia 2014-2020 "Andalucía is moving with Europe" and the Spanish Ministry of Economy, Industry and Competitiveness; through the research project (hydroSOS mark) including the Universidad Miguel Hernández de Elche (AGL2016-75794-C4-1-R, hydroSOS foods) and the Universidad de Sevilla (AGL2016-75794-C4-4-R). The author S. Gutiérrez-Gordillo has a contract co-financed by the National Institute of Agrarian and Food Research and technology (FPI-INIA 2016) and European Social Fund (ESF) "The European Social Fund invests in your future."

Conflicts of Interest: The authors declare no conflict of interest.

\section{References}

1. García-Tejero, I.F.; Durán, Z.V.H.; Rodríguez, P.C.R.; Muriel, F.J.L. Water and Sustainable Agriculture. In Springerbriefs Agriculture; Springer: Dordrecht, The Netherlands, 2011; p. 94.

2. Garrote, L.; Granados, A.; Iglesias, A. Strategies to reduce water stress in Mediterranean river basins. Sci. Total Environ. 2015, 543, 997-1009. [CrossRef] [PubMed]

3. Iglesias, A.; Garrote, L. Adaptation strategies for agricultural water management under climate change in Europe. Agric. Water Manag. 2015, 155, 113-124. [CrossRef]

4. Lorite, I.J.; Ruiz-Ramos, M.; Gabaldón-Leal, C.; Cruz-Blanco, M.; Porras, R.; Santos, C. Water Management and Climate Change in Semi-Arid Environments. In Water Scarcity and Sustainable Agriculture in Semi-Arid Environments; García-Tejero, I.F., Durán Zuazo, V.H., Eds.; Elsevier-AP: Cambridge, MA, USA, 2018; pp. 3-40.

5. García-Tejero, I.F.; Durán, Z.V.H.; Muriel, F.J.L. Towards sustainable irrigated Mediterranean agriculture: Implications for water conservation in semi-arid environments. Water Int. 2014, 39, 635-648. [CrossRef]

6. García Tejero, I.F.; Moriana, A.; Rodríguez, P.C.R.; Durán, Z.V.H.; Egea, G. Deficit-Irrigation Management in Almonds (Prunus dulcis L.): Different Strategies to Assess the Crop Water Status. In Water Scarcity and Sustainable Agriculture in Semiarid Environment; García-Tejero, I.F., Durán-Zuazo, V.H., Eds.; Elsevier-AP: Cambridge, MA, USA, 2018; pp. 271-298.

7. FAOSTAT. Food and Agriculture Organization of the United Nations. 2018. Available online: http: //www.fao.org/faostat/en/\#data/QC (accessed on 1 March 2020).

8. MAPA. Ministerio de Agricultura, Pesca y Alimentación. Superficies y Producciones Anuales de Cultivos. 2019. Available online: https://www.mapa.gob.es/es/estadistica/temas/estadisticas-agrarias/agricultura/ superficies-producciones-anuales-cultivos/ (accessed on 8 April 2020). 
9. OPM. Observatorio de Precios y Mercados. Consejería de Agricultura, Ganadería, Pesca, y Desarrollo Sostenible. Junta de Andalucía. Available online: https://www.cap.junta-andalucia. es/agriculturaypesca/observatorio/servlet/FrontController?action=Static\&subsector=35\&producto= 35000\&url=generadorInformesOR.jsp (accessed on 10 June 2020).

10. USDA. U.S. Department of Agriculture. Tree Nuts Annual EU-28. Glob. Agric. Inf. Netw. Available online: https://gain.fas.usda.gov/RecentGAINPublications/TreeNutsAnnual_Madrid_EU-28_9-18-2017.pdf (accessed on 23 October 2020).

11. CAPDR. Caracterización del sector de la almendra en Andalucía. Secretaría General de Agricultura y Alimentación, Consejería de Agricultura, Pesca y Desarrollo Rural. Junta de Andalucía. Available online: http://www.juntadeandalucia.es/agriculturaypesca/observatorio/servlet/FrontController?action= RecordContent\&table=12030\&element=1654785. (accessed on 3 March 2020).

12. MAPA. Ministerio de Agricultura, Pesca y Alimentación. Anuario de estadística agraria 2019. Available online: https:/www.mapa.gob.es/es/estadistica/temas/publicaciones/anuario-de-estadistica/2019/default. aspx parte $=3 \&$ capitulo=07\&grupo=10\&seccion=1 (accessed on 28 March 2020).

13. Arquero, O. Manual del almendro. Consejería de Agricultura, Pesca y Desarrollo Rural, Junta de Andalucia Sevilla, España. 2013. Available online: https://www.juntadeandalucia.es/servicios/publicaciones/detalle/ 77668.html (accessed on 16 May 2020).

14. Girona, J.; Marsal, J.; Cohen, M.; Mata, M.; Miravete, C. Physiological, growth and yield responses of almond (Prunus dulcis L.) to deficit irrigation regimes. Acta Hortic. 1993, 335, 389-398. [CrossRef]

15. Girona, J.; Mata, M.; Marsal, J. Regulated deficit irrigation during the kernel-filling period and optimal irrigation rates in almond. Agric. Water Manag. 2005, 75, 152-167. [CrossRef]

16. Egea, G.; Nortes, P.A.; González, R.M.M.; Baille, A.; Domingo, R. Agronomic response and water productivity of almond trees under contrasted deficit irrigation regimes. Agr. Water Manag. 2010, 97, 171-181. [CrossRef]

17. Gutiérrez-Gordillo, S.; Durán, Z.V.H.; García, T.I.F. Response of three almond cultivars subjected to different irrigation regimes in Guadalquivir river basin. Agric. Water Manag. 2019, 222, 72-81. [CrossRef]

18. López-López, M.; Espadafor, M.; Testi, L.; Lorite, I.J.; Orgaz, F.; Fereres, E. Water requirements of mature almond trees in response to atmospheric demand. Irrig. Sci. 2018, 36, 271-280. [CrossRef]

19. Romero, P.; García, J.; Botía, P. Cost-benefit analysis of a regulated deficit-irrigated almond orchard under subsurface drip irrigation conditions in South-eastern Spain. Irrig. Sci. 2006, 24, 175-184. [CrossRef]

20. Cano-Lamadrid, M.; Girón, I.F.; Pleite, R.; Burló, F.; Corell, M.; Moriana, A.; Carbonell-Barrachina, A.A. Quality attributes of table olives as affected by regulated deficit irrigation. LWT Food Sci. Technol. 2015, 62, 19-26. [CrossRef]

21. Lipan, L.; Sánchez, R.L.; Collado, G.J.; Sendra, E.; Burló, F.; Hernández, F.; Vodnar, D.C.; Carbonell-Barrachina, A.A. Sustainability of the legal endowments of water in almond trees and a new generation of high quality hydrosustainable almonds-A review. Bull. USAMV. Food Sci. Technol. 2018, 75, 98-108. [CrossRef]

22. Noguera-Artiaga, L.; Lipan, L.; Vázquez, A.L.; Barber, X.; Pérez, L.D.; Carbonell-Barrachina, A.A. Opinion of Spanish consumers on hydrosustainable pistachios. J. Food Sci. 2016, 81, S2559-S2565. [CrossRef]

23. Carbonell-Barrachina, A.A.; Memmi, H.; Noguera, A.L.; Gijón, L.M.D.; Ciapa, R.; Pérez, L.D. Quality attributes of pistachio nuts as affected by rootstock and deficit irrigation. J. Sci. Food Agric. 2015, 95, 2866-2873. [CrossRef] [PubMed]

24. Cano-Lamadrid, M.; Hernández, F.; Corell, M.; Burlo, F.; Legua, P.; Moriana, A.; Carbonell-Barrachina, A.A. Antioxidant capacity, fatty acids profile, and descriptive sensory analysis of table olives as affected by deficit irrigation. J. Sci. Food Agric. 2017, 97, 444-451. [CrossRef] [PubMed]

25. Lipan, L.; Martín, P.M.J.; Sánchez, R.L.; Cano-Lamadrid, M.; Sendra, E.; Hernández, F.; Burló, F.; Vázquez-Araújo, L.; Andreu, L.; Carbonell-Barrachina, á.A. Almond fruit quality can be improved by means of deficit irrigation strategies. Agric. Water Manage. 2019, 217, 236-242. [CrossRef]

26. Lipan, L.; García-Tejero, I.F.; Gutiérrez, G.S.; Demirbaş, N.; Sendra, E.; Hernández, F.; Durán, Z.V.H.; Carbonell-Barrachina, A.A. Enhancing nut quality parameters and sensory profiles in three almond cultivars by different irrigation regimes. J. Agric. Food Chem. 2020, 68, 2316-2328. [CrossRef]

27. USDA. U.S. Department of Agriculture, Agricultural Research Service, Nutrient Data Laboratory. Basic Report: 12061, Nuts, almonds. In USDA National Nutrient Database for Standard Reference; National Agricultural Library: Washington, DC, USA, 2018. 
28. Yada, S.; Lapsley, K.; Huang, G. A review of composition studies of cultivated almonds: Macronutrients and micronutrients. J. Food Anal. 2011, 24, 469-480. [CrossRef]

29. Civille, G.V.; Lapsley, K.; Huang, G.; Yada, S.; Seltsam, J. Development of an almond lexicon to assess the sensory properties of almond varieties. J. Sens. Stud. 2010, 25, 146-162. [CrossRef]

30. Vickers, Z.; Peck, A.; Labuza, T.; Huang, G. Impact of almond form and moisture content on texture attributes and acceptability. J. Food Sci. 2014, 79, S1399-S1406. [CrossRef]

31. Lipan, L.; Moriana, A.; López Lluch, D.B.; Cano-Lamadrid, M.; Sendra, E.; Hernández, F.; Carbonell-Barrachina, A.A. Nutrition quality parameters of almonds as affected by deficit irrigation strategies. Molecules 2019, 24, 2646. [CrossRef]

32. Kwak, J.; Faranda, A.; Henkin, J.M.; Gallagher, M.; Preti, G.; McGovern, P. Volatile organic compounds released by enzymatic reactions in raw nonpareil almond kernel. Eur. Food Res. Technol. 2015, 241, 441-446. [CrossRef]

33. Xiao, L.; Lee, J.; Zhang, G.; Ebeler, S.E.; Wickramasinghe, N.; Seiber, J.; Mitchell, A.E. HS-SPME GC/MS characterization of volatiles in raw and dry-roasted almonds (Prunus dulcis). Food Chem. 2014, 151, 31-39. [CrossRef] [PubMed]

34. USDA. Keys to Soil Taxonomy. In United States Department of Agriculture Natural Resources Conservation Service, 11th ed.; National Agricultural Library: Washington, DC, USA, 2010.

35. Gutiérrez-Gordillo, S.; Durán, Z.V.H.; Hernández, S.V.; Ferrera, G.F.; García, E.A.; Amores, A.J.J.; García-Tejero, I.F. Cultivar dependent impact on yield and its components of young almond trees under sustained-deficit irrigation in semi-arid environments. Agronomy 2020, 10, 733. [CrossRef]

36. Allen, R.G.; Pereira, L.S.; Raes, D.; Smith, M.W.B. Crop evapotranspiration-Guidelines for computing crop water requirements-FAO Irrigation and drainage paper 56. Irrig. Drain. 1998, 300, 1-15.

37. García-Tejero, I.F.; Hernández, A.; Rodríguez, V.M.; Ponce, J.R.; Ramos, V.; Muriel, J.L.; Zuazo, V.H.D. Estimating Almond Crop Coefficients and Physiological Response to Water Stress in Semiarid Environments (SW Spain). J. Agric. Sci. Technol. 2015, 17, 1255-1266.

38. Myers, B.J. Water stress integral-A link between short-term stress and long-term growth. Tree Physiol. 1988, 4, 315-323. [CrossRef] [PubMed]

39. Gomes-Laranjo, J.; Coutinho, J.P.; Galhano, V.; Cordeiro, V. Responses of five almond cultivars to irrigation: Photosynthesis and leaf water potential. Agric. Water Manag. 2006, 83, 261-265. [CrossRef]

40. García-Tejero, I.F.; Gutiérrez, G.S.; Souza, L.; Cuadros, T.S.; Durán, Z.V.H. Fostering sustainable water use in almond (Prunus dulcis Mill.) orchards in a semiarid Mediterranean environment. Arch. Agron. Soil Sci. 2018, 65, 164-181. [CrossRef]

41. López-López, M.; Espadafor, M.; Testi, L.; Lorite, I.J.; Orgaz, F.; Fereres, E. Yield response of almond trees to transpiration deficits. Irrig. Sci. 2018, 36, 111-120. [CrossRef]

42. Alegre Castellví, S.; Miarnau i Prim, X.; Romero, R.M.; Vargas, G.F. Potencial productivo de seis variedades de almendro. Frutic. Prof. 2007, 169, 23-29.

43. Miarnau, X.; Torguet, L.; Batlle, I.; Romero, A.; Rovira, M.; Alegre, S. La revolución del almendro: Nuevas variedades y nuevos modelos productivos. In Proceedings of the Simp. Nac. Almendro Otros Frutos Secos, Lérida, Spain, 24 September 2015; pp. 6-27.

44. Sanders, G.J.; Arndt, S.K. Osmotic Adjustment under Drought Conditions Plant Responses to Drought Stress; Springer: Berlin/Heidelberg, Germany, 2012.

45. Ahanger, M.A.; Morad-Talab, N.; Abd-Allah, E.F.; Ahmad, P.; Hajiboland, R. Plant growth under drought stress: Significance of mineral nutrients. In Water Stress and Crop Plants: A Sustainable Approach; Parvaiz, A., Ed.; John Wiley \& Sons, Ltd.: Hoboken, NJ, USA, 2016; Volume 2-2, pp. 649-668.

46. Lipan, L.; Cano-Lamadrid, M.; Corell, M.; Sendra, E.; Hernandez, F.; Stan, L.; Vodnar, D.C.; Vázquez, A.L.; Carbonell-Barrachina, A.A. Sensory Profile and Acceptability of HydroSOStainable Almonds. Foods 2019, 8, 64. [CrossRef]

47. Erten, E.S.; Cadwallader, K.R. Identification of predominant aroma components of raw, dry roasted and oil roasted almonds. Food Chem. 2017, 217, 244-253. [CrossRef] [PubMed]

48. Horner, J.D. Nonlinear effects of water deficits on foliar tannin concentration. Biochem. Syst. Ecol. 1990, 18, 211-213. [CrossRef]

49. Ali, M.S.; Baek, K.H. Jasmonic Acid Signaling Pathway in Response to Abiotic Stresses in Plants. Int. J. Mol. Sci. 2020, 21, 621. [CrossRef] 
50. Bolling, B.W. Almond polyphenols: Method of analysis, contribution to food quality and health promotion. Compr. Rev. Food Sci. Food Saf. 2017, 16, 346-368. [CrossRef]

51. Monagas, M.; Garrido, I.; Lebrón-Aguilar, R.; Bartolomé, B.; Gómez-Cordovés, C. Almond (Prunus dulcis (Mill.) D.A. Web) skins as a potential source of bioactive polyphenols. J. Agric. Food Chem. 2007, 55, 8498-8507. [CrossRef] [PubMed]

52. Freitas, V.d.; Mateus, N. Protein/polyphenol interactions: Past and present contributions. Mechanisms of astringency perception. Curr. Org. Chem. 2012, 16, 724-746. [CrossRef]

53. NIST. National Institute of Standards and Technology (Libro del Web de Química del NIST. SRD69. In, U.S. Secretary of Commerce on behalf of the United States of America). Available online: https: //webbook.nist.gov/chemistry/ (accessed on 30 June 2019).

54. Company, T.G.S. The Good Scents Company Information System. 2018. Available online: http://www. thegoodscentscompany.com (accessed on 30 June 2019).

55. NCBI. National Center for Biotechnology Information, U.S.N.L.o.M. PubChem open Chemistry Database. Available online: https://pubchem.ncbi.nlm.nih.gov/ (accessed on 30 June 2019).

56. Charalambous, G. Food Flavors: Generation, Analysis and Process Influence, 1st ed.; Elsevier Science: Amsterdam, The Netherlands, 1995; Volume 37B, p. 1360.

57. Yang, J.; Pan, Z.; Takeoka, G.; MacKey, B.; Bingol, G.; Brandl, M.T.; Wang, H. Shelf-life of infrared dry-roasted almonds. Food Chem. 2013, 138, 671-678. [CrossRef]

58. Hojjati, M.; Lipan, L.; Carbonell-Barrachina, A.A. Effect of roasting on physicochemical properties of wild almonds (Amygdalus scoparia). J. Am. Oil Chem. Soc. 2016, 93, 1211-1220. [CrossRef]

Publisher's Note: MDPI stays neutral with regard to jurisdictional claims in published maps and institutional affiliations. 